\section{A COMPARATIVE ANALYSIS OF ENTRY TO HOME OWNERSHIP PROFILES: TURKEY AND THE NETHERLANDS \\ G. Pelin SARIOĞLU ERDOĞDU}

Received: 28.07.2009

Keywords: owner occupancy; housing systems; Turkey; the Netherlands.

1. The paper is partly derived from Sarıoğlu et al. (2007) and Sarıoglu (2008).

\section{INTRODUCTION}

Entry to home ownership (EHO) is one of the most significant steps that a household takes during household careers (1). It is not only an economic decision of households but also a social and cultural attitude towards housing. It has spatial repercussions within the urban arena as well. In the literature, the process of entry to home ownership has been studied numerous times (Fejitsen and Mulder, 2002; Megbolugbe and Linneman (1993); Clark, Deurloo and Dieleman (1997); Dieleman and Everaers (1994); Mulder and Wagner (1998) etc.) for different countries. In many of them, factors hypothetically affect this process are found similar and may be grouped under four headings as: household status, characteristics of housing stock, socio-cultural factors, housing finance and external factors. EHO process involves additionally, socio-economic and demographic characteristics of countries and ideological and political contexts.

Housing is one of the indicative attributes with joint significance in socioeconomic performance for any country. Due to socio- cultural, economical and urbanization processes experienced, policies implemented and their effects in the stock could be wide-ranged. In Turkey, free market processes with almost no intervention ruled under circumstances of rapid urbanization. In the Netherlands, to meet the urgent housing need which arose after Second World War, centralized social housing policies were dominant. The influences of these policies in the stock also varied considerably putting owner occupation and renting in distinct positions in the two countries.

Historically, housing policy profiles of Turkey and the Netherlands differ due to the socio-economic processes the countries experienced. The Second World War in the Netherlands, for instance, was severe: a considerable part of the housing stock had been ruined because of war and new housing was desperately needed. To meet the urgent housing need, state intervention 
was inevitable. Social housing policy was developed and strictly followed until the 1990s, after which significant policy changes came into effect.

Turkey was not involved in the Second World War, and housing need was not necessarily a post war problem necessitating state involvement. Rather, housing need became a problem after the 1980s when migration to big cities began due to several processes that Turkey was experiencing. In Turkey, the severe housing need that arose in 1980s, was primarily met by the private developer entrepreneurs and in terms of various processes of private provision in the market (Balamir, 1975; 1982; 1996a). The role of the government has generally been passive, and direct provision was not carried by the central or local governments in Turkey, except after big natural disasters.

Historical events and responding policies to the problem of housing varied in Turkey and the Netherlands. Deliberately or not, while the former allowed the development of the stock by private entrepreneurs, the latter chose to devote such powers to its central government. This discrepancy in housing policies in the two countries implied tenure type disparities as well. While in the Netherlands 'public renting' appeared to be the solution, 'owner occupation' became the distinguishing feature in Turkey. As a result, the two countries represent opposites in terms of their housing policies.

These distinct policies resulted in different achievements and problems. In the Netherlands, for instance, extensive social housing policy solved housing shortage and shelter problems. However in the long term, this policy resulted in a stagnant market and put financial burdens on governments (Boelhouwer and van der Heijden 1992). Implementation of subsidy programs further led to household and housing unit mismatches (Dieleman and Van Kempen, 1994). Through development of mortgage law and promotion of owner occupation, the system attempts to give greater choice options to households in recent years. In the Turkish case, on the other hand, the incapacity to intervene in the market provision of housing led to the development of unauthorized housing in various forms including gecekondu. Especially after the 1960s, with massive migration from rural areas to big cities, the problem of housing became a substantial problem (Sarığlu, 2007).

Housing systems deliberately or not favored one tenure type over the other, and the socio-economic circumstances experienced in countries lead emergence of a variety of modes of access to home ownership which can be grouped as Entry to home ownership profiles (EHOPs). Due to these socioeconomic processes, distinct paths have evolved in home owner trajectories defined in this study as "entry to home ownership profiles" (EHOPs) in the two countries. Any EHOP refers to a particular way of becoming home owner, reflecting the repercussions from the contextual differences in demography, housing systems and housing stocks in the two countries. Throughout the paper, by the term "EHOP", paths households follow in order to become owner occupiers is meant. These profiles are highly associated with the socio-economic circumstances of households and countries. Therefore, they do differ significantly from country to country. EHOPs defined for a country do not add up to cover positions of all owner occupiers rather reveal the prevalent ways to $\mathrm{OO}$ in the both countries.

In this paper, profiles formed out of those processes are examined.

Before examining the EHOPs of the two countries, however, the two 
housing systems are evaluated. In doing so, data like population and building census and inflation rates are employed. Additionally, raw data sets of Household Budget Survey (HBS, 2003) for Turkey and Housing Demand Survey (Woningbehoefte Onderzoek-WBO-2002) for the Netherlands are processed. HBS is prepared by State Institute of Statistics (TURKSTAT) and WBO by Ministry of Housing, Spatial Planning and the Environment (VROM). The Dutch survey is a more comprehensive data set which provides information on the previous housing and household characteristics of the households. These data sets are fortunately similar to each other in several attributes making a cross country research possible. Primary variables (such as tenure status and household size, age of $\mathrm{Hh}$ Head etc) which are included in the analysis are available in both data sets.

\section{POPULATION AND DEMOGRAPHIC ATTRIBUTES IN THE TWO COUNTRIES}

The Turkish population is comparatively higher among Western Countries (2). Since the foundation of the Republic, the Turkish population increased more than 5 times in 80 years and reached to over 70 million in 2007. Not only the total figures but also the population increases in the two countries are divergent. In the same period of time, from 1927 to 2007, Dutch population doubled which is a comparatively modest increase for such a long period of time. The Turkish population increased more than 5 times. These population differences have created distinct demands in the two housing stocks. The quantity of housing demand inevitably has been a priority in Turkey much more than it has been in the Netherlands.

In the same period, the urbanization level of Turkey also changed dramatically; Turkey became a $70.5 \%$ urban country from a $75 \%$ rural country (3). Migration figures further support the rapid urbanization Turkey experienced. The ratio of migrated population to cities comprises almost $13 \%$ of all urban population in the 1975-2000 period (Sarığlu, 2007).

Turkey is characterized with a young population. $26.4 \%$ of the total population is younger than 15 years old (2007). This ratio has a decreasing tendency though: it reached from $41.4 \%$ in 1935 to $29.7 \%$ in year 2000 (4). Although currently characterized with a younger population, the figures support that the Turkish population is getting older. The Netherlands, on the contrary, experienced this population trend previously and its population is now characterized with population ageing. Only $24 \%$ of its

2. http:/ / ocde.p4.siteinternet.com/ publications/doifiles/01-01-01t1.xls (accessed on 16.12.2008)

3. Processed from www.tuik.gov.tr.

4. http:/ / www.tuik.gov.tr/VeriBilgi.do?tb $\mathrm{id}=39$ \&ust_id=11 accessed in 05.2009.

5. http: / / statline.cbs.nl/

StatWeb/publication/

?DM=SLEN\&PA $=37556$ eng\&D1 $=4-8 \& D 2=1,1$ $1,21,36,41,51,61,71,81,91,101,1 \& \mathrm{LA}=\mathrm{EN} \& \mathrm{HDR}$ $=\mathrm{G} 1 \& \mathrm{STB}=\mathrm{T} \& \mathrm{VW}=\mathrm{T}$ accessed in May 2009.

6. Priemus $(2001 b, 278)$ denotes that economic growth boosts separate household formation and when the economy is growing, individual members in a household could have adequate income to secure a dwelling in the housing market and to start a household of their own. population is now younger than 20 years old. The share of this age group was $38 \%$ in 1935, 25.6\% in 1990 and decreased to $24.4 \%$ in 2000 (5).

Age composition of the populations provides insights for demands in housing, including tenure choice, preferences in type and size of the dwellings etc. They should be carefully analyzed together with other factors, since, contrary to the literature, a younger population does not necessarily imply higher renting ratios (as in Turkish case) while older population does not always favor owning (as in the Netherlands).

Another difference between the two populations is observed in household formation. Individual household formation starts at younger ages in the Netherlands which could be linked to higher GDP per capita (6) and prevalent individualistic life styles. As Coleman and Garssen (2002) denote, marriage without cohabitation is almost exceptional in the Netherlands. More than half of the persons leaving home first set 
7. Of the all 25764 households in the HBS 2003, only 8 were cohabiting couples.

8. 2000 Population Census, www.tuik.gov.tr (accessed on 06.11.2008).

9. http://www.tuik.gov.tr/

PreHaberBultenleri.do?id=519 (accessed on 23.03.2009).

10. www.cbs.nl Marriages and partnership registrations; key figures (accessed on 11.12.2008).

11. http: / / www.tuik.gov.tr/

PreHaberBultenleri.do?id=519 (accessed on 23.06.2008). This ratio is called rough divorce rate (Kaba boşanma hizl) and refers to the number of divorces in 1000 population for a given year.

12. www.cbs.nl (accesed on 11.12.2008).

13. http://www.cbs.nl/en-GB/menu/ themas/bevolking/publicaties/artikelen/ archief/2008/2008-2546-wm.htm (accessed on 15.12.2008). single person household even before a partnership. Similarly, the three generation households are very exceptional in the Netherlands supporting the argument of Coleman and Garssen $(2002,454)$ that the Dutch seem to be disinclined to economize on space by living with their relatives, or indeed with anyone else. On the contrary, cohabiting without marriage is very rare in Turkey (7), almost nonexistent in rural areas, and single person households are set mostly when the person moves to another city for university or for work. While living in the same city, generally speaking, separate single person household is not formed even at ages over 30. Three generation households are fairly common especially in rural areas, increasing the average household sizes in Turkey. Although, the ratio of $\leq 24$ aged persons in the whole population is $50.3 \%$ (8), only $1 \%$ forms separate private households in Turkey. This is an indicator showing that Turkish people form private households at later ages than in most European countries. Generally speaking, in Turkey, leaving the family takes place as a result of marrying and/or moving to a different city for working or studying (Sarıoğlu et. al, 2007), unlike many Western countries where after the age of 18 it is common to form a private household no matter the education and/or marriage circumstances of the people.

However, Turkish people on average marry at younger ages: the average age of first marriage for men is 26.1 and for women 22.8 in Turkey (9). In the Netherlands, yet, average age at first marriage for men is 36.3 and for women 33.2 (10). Household disintegration, as well, is quite distinct in Turkey. Marriage is still one of the strongest social bonds in the society which is positively assessed as an institution. In 2006, divorce rate for whole Turkey was only $1.28 \%$ (11). However, in the Netherlands, divorce rate is $9.2 \%$ (per 1000 couples) (12). This is also reason for the high ratio of single parent households in the Netherlands. In 2008, there are 466 thousand single parents in the Netherlands. Since 1995, the number of single parent households increased by 30 percent which is estimated to reach 494 thousand in 2016 (13).

Therefore, the fact that Turkish people form private households at later ages could lead to "ownership at later ages" as well, since the individual housing careers begin later than the Netherlands. Yet, if the household formation is mostly due to marriage, which is the usual case in Turkey, it triggers EHO since marriage is one of the most significant triggers of EHO. In the housing stock, this characteristic may imply that in Turkey when private household is formed, it is at a phase that households had already came to an age and have stable features which are convenient to be home owners rather than staying in the rental sector. This tendency of Turkish households may indicate cultural significance of the tenure in the estimation of households as well as their immobile character due to several barriers such as limitations in the stock, financial burdens of transaction costs etc.

For the Netherlands, however, marriage can not be argued to have a direct influence in EHO as, generally speaking; household formation does not necessarily happen due to marriage (which includes many positive for owning like increased commitment and stability levels, having children etc). There is a period of time that Dutch households prefer to be mobile due to unstable household attributes they have. This characteristic has repercussions in tenure choice. No matter the income they earn, for that group of households renting would be a better option for a certain period of time. The length of this time can be argued to be longer than the Turkish 


\begin{tabular}{|c|c|c|c|c|c|}
\hline & \multicolumn{3}{|l|}{ Turkey } & \multicolumn{2}{|l|}{ The Netherlands } \\
\hline & Urban Hhs & Total number of households & $\begin{array}{l}\text { Average } \\
\text { Hh size }\end{array}$ & $\begin{array}{l}\text { Total number of households } \\
(x \text { 1000) }\end{array}$ & $\begin{array}{l}\text { Average } \\
\text { Hh size }\end{array}$ \\
\hline 1955 & $4,237,176$ & $6,927,343$ & 5.67 & 2848 & 3.93 \\
\hline 1960 & $4,885,325$ & $8,859,731$ & 5,68 & 3171 & 3.71 \\
\hline 1965 & $5,536,116$ & $10,805,817$ & 5,67 & 3508 & 3.45 \\
\hline 1970 & $6,261,949$ & $13,691,101$ & 5,69 & 3986 & 3.21 \\
\hline 1975 & $6,982,505$ & $16,869,068$ & 5,78 & 4561 & 2.95 \\
\hline 1980 & $8,522,499$ & $19,645,007$ & 5,25 & 5006 & 2.78 \\
\hline 1985 & 9730018 & $26,865,757$ & 5,21 & 5613 & 2.54 \\
\hline 1990 & $11,188,636$ & $33,326,351$ & 5,05 & 6061 & 2.42 \\
\hline 2000 & $15,070,093$ & $44,006,274$ & 4,50 & 6469 & 2.30 \\
\hline 2008 & NIA & NIA & NIA & 6801 & 2.24 \\
\hline
\end{tabular}

Table 1. Number of households and average Hh size, Turkey, The Netherlands (1955-2007) Note. The Turkish data on the total household population have not been tabulated for the years before 1975. For that reason, the average size of households has been calculated by total population for these years. (www.tuik.gov.tr, accessed 22.07.2008) Urban and rural figures are derived from total number of households and urban and rural ratios. NIA: No information available. For number of households the most recent data comes from 2000 population census.
14. http:// www.tuik.gov.tr/VeriBilgi.do?tb $\mathrm{id}=39$ \&ust $\mathrm{id}=11$ (accessed at 27.06.2008).

15. http: / / statline.cbs. $\underline{\mathrm{nl} / \text { StatWeb/publication/ }}$ ?DM=SLEN\&PA $=37312$ en $\& \& D 1=4-8,32-36,41$ $46 \& \mathrm{D} 2=0,5,10,1 \& \mathrm{LA}=\mathrm{EN} \& \mathrm{HDR}=\mathrm{T} \& \mathrm{STB}=\mathrm{G} 1$ $\& \mathrm{VW}=\mathrm{T}$ (accessed on 15.12.2008). one since average marriage age is higher and private household formation is earlier in the Netherlands. The general household formation process in the Netherlands therefore may represent a structure of 'first renting then owning'. In Turkey, as a result of dominancy of household formation due to marriage, housing careers may begin with owning in many cases, when possible.

Rather than population figures, number of households could provide better insights. In Turkey, although the population is over 70 million (2007), the number of households is 15 million (2000) (14). When compared to The Netherlands, where population is over 16 million with almost 7.2 million (2007) households, the significant Hh Size and demographic dissimilarities between the two countries can be comprehended. The varieties certainly have reflections in housing systems.

When the number of households in the two countries is assessed regarding total population figures, Hh size differences can be seen as well. In terms of Hh size, Turkey has been characterized with large households. Regarding previous years, however, average Hh size is on decrease. In 2003, results of Household Budget Survey (HBS) demonstrate that average Hh size in urban areas is even smaller: 4.0. 1 person households comprise only $3.9 \%$ of the urban population. These figures are still high and when compared to Western countries.

Large Hh size in Turkey mainly stems from high number of children and existence of 3 generation households ( $15 \%$ ) even in the urban areas. However, Hh size is decreasing because of increases in the ratio of single households and decreases in the ratio of 3 generation households especially in urban Turkey. High Hh size generally indicates high stability and commitment levels which positively affect entry to home ownership. Thus, it is anticipative that high household size in Turkey would bring a high stability level which is strongly associated with becoming a home owner. Further, it is expected that the stock in Turkey should have larger dwellings with more rooms to meet the needs of households (Sarığlu et al. 2007).

In the Netherlands, average Hh size is smaller. From 3.93 in 1955, average Hh size decreased gradually to 2.24 in 2008. The figures are strongly related with high ratio of single households (35\% in 2007) (15) and almost total absence of 3 generation households. In terms of tenure choice, small Hh size may indicate on the one hand dissolved families, and therefore less 
stability, less need for space etc which may lead to renting preferences. Yet, on the other hand, small Hh size still may be indicative of married couples with higher commitment levels. On this account, small Hh size does not necessarily favor one type of tenure choice over the other.

As housing policies are developed regarding these demographic factors, housing need, tenure type and physical attributes of housing stock will certainly be distinct in Turkey and the Netherlands. Personal and cultural preferences would be totally different for both cases; the dominance of small dwellings would not necessarily lead overcrowding in the Netherlands. In Turkey, with large households, prevalence of small sized dwellings would certainly result in overcrowding.

\section{TENURE AND HOUSING STOCK IN THE TWO COUNTRIES}

\section{a. Turkey}

Rapid urbanization process in an almost uncontrolled housing system resulted in a unique tenure typology pattern in Turkey leading to the dominance of home ownership, followed by private renting and unauthorized building stock (Table 2). Housing choices of Turkish households did not follow the cliché dynamics such as 'if householder expects a child, then a bigger house is desired, then likelihood of becoming home owner increases since owner occupied housing is on average larger,' etc. Rather, primary motives in housing went hand in hand with household concerns to decrease future ambiguities and financial matters like; 'if a house can be bought- no matter seeking the proper matching-, more money can be saved, then it becomes easier to buy the second one which can be rented out and capital returns can be realised,' etc. This understanding of home ownership as a medium in solving both housing issues and future

Table 2. Turkey- Urban-Rural tenure ratios (1987, 1990, 1994, 2000, 2003).

TURKSTAT,1993 Socio-economic Indicators, p. 15.

1990 General Population Census (GPC),

Socio-economic characteristics of population, 1993 , p. 186

2000 General Population Census (GPC),

Socio-economic characteristics of population, 2003. p 236.

1994 Processed from Household Income and Consumption Expenditures Survey Raw data. 2003 Processed from Household Budget

\begin{tabular}{|c|c|c|c|c|}
\hline & & Total & Urban & Rural \\
\hline \multirow{4}{*}{1987} & Owner occupier & 71.20 & 60.62 & 82.92 \\
\hline & Tenancy & 21.93 & 33.04 & 9.64 \\
\hline & Public accommodation & 2.67 & 2.51 & 2.84 \\
\hline & Other & 4.20 & 3.83 & 4.60 \\
\hline \multirow{4}{*}{$\begin{array}{l}1990 \\
\text { (GPC) }\end{array}$} & Owner occupier & 70.20 & 58.91 & 89.25 \\
\hline & Tenancy & - & - & - \\
\hline & Public accommodation & - & - & - \\
\hline & Other & - & - & - \\
\hline \multirow{4}{*}{1994} & Owner occupier & 70.88 & 59.02 & 86.06 \\
\hline & Tenancy & 19.71 & 29.84 & 6.74 \\
\hline & Public accommodation & 1.76 & 1.62 & 1.94 \\
\hline & Not owner but not paying rent & 7.65 & 9.52 & 5.25 \\
\hline \multirow{5}{*}{$\begin{array}{l}2000 \\
\text { (GPC) }\end{array}$} & Owner occupier & 68.28 & 59.77 & 86.75 \\
\hline & Tenancy & 23.91 & 31.69 & 7.04 \\
\hline & Public accommodation & 2.05 & 2.20 & 1.74 \\
\hline & Not owner but not paying rent & 4.84 & 5.46 & 3.50 \\
\hline & Other & 0.92 & 0.88 & 0.97 \\
\hline \multirow{4}{*}{2003} & Owner occupier & 71.95 & 64.16 & 85.69 \\
\hline & Tenancy & 21.60 & 28.01 & 10.28 \\
\hline & Public accommodation & 1.33 & 1.39 & 1.23 \\
\hline & Not owner but not paying rent & 5.13 & 6.44 & 2.80 \\
\hline
\end{tabular}


16. HDA (2006) Research Series, No: 2.; 85.

17. HDA (2008), Housing Implementation Programme Summary.

18. Figures represents only the dwellings constructed by Housing Administration, and does not comprise the total number of dwellings constructed.

19. Turkish urbanization process has been examined from distinct perspectives among Turkish scholars. Balamir (1982, 1996a, 1999) for instance, links the Turkish urbanization process mostly to the absence of sufficient capital accumulation in urban areas and to the existence of socio-economic relations which arose due to flat ownership. On the other hand, scholars like Senyapilı $(1998,2004)$ attempt to describe Turkish urbanization process from the physical outcomes, like gecekondu in cities, and primarily associates Turkish urbanization process with "urban pull-rural push" relations. ambiguities led to a vicious circle in which households are forced to become home owners where there is almost no better choice in Turkey.

From the perspective of administrations as well, housing problem of the citizens was considered together with macro concerns like growth and improvement of economic conditions. The multiplier effects of housing industry are welcomed especially by right wing parties as saver of recession periods. Like the emphasis of US administrations on home ownership considering its community improvement effects, in Turkey, housing is mostly regarded with its macro economic repercussions. The Justice and Development Party's strong emphasis on "housing mobilization" which was initiated during their first government period (2002-2007) is mostly due to multiplier effects of housing industry in the macro economy, rather than real demands for housing. As a part of this mobilization project, in approximately 2 years, the aim was to begin construction of 150000 (16), and in 9 years -until 2011- 500000 new dwellings (17), (HDA, 2008) all over the country (18).

The high home ownership ratios that could be maintained even in the absence of a housing finance system in Turkey is due to serious concerns of households both for "shelter" and "future ambiguities" which made housing the best option to solve the both. Therefore, obstacles -like the absence of a financial system- in entry to home ownership could be overcome by informal and personal debt relations for many households. Households devoted financial resources unreservedly. This choice then proved home ownership as the safest way for housing problem not only for themselves but also for next generations, their children as well. Rather than seeking for a proper housing-household match, primary aim was just to become home owners since even the smallest-oldest units could provide capital gains, while in addition, solving their housing problem. Further, once became home owners, it has been easier to save for the second and third homes by which greater capital returns could be realized due to the possibility of private renting out in Turkey. As home ownership provided many positive extras to its owners, more and more households have been attracted resulting in emergence of a class of home owners who are asset rich. This of course does not imply that they are "income poor" considering the credit debt payments; rather, real estate incomes may increase total incomes in numerous cases. Home ownership thus has been not only a matter of shelter but also a matter of earning capital returns in Turkey resulting in ambitions of home ownership. This process eventually caused 'emergence of a household class of home owners' who, from the other side of the coin, are the owners of private rented sector as well. This process eventually caused 'emergence of a household class of home owners' who, from the other side of the coin, are the owners of private rented sector as well. These groups of households who are multi owners, who do not pay rent themselves, who earn rental incomes, represent a prevalent understanding of "mercenary ownership".

Similar to high home ownership ratios, high private rented ratios in Turkey arose because of the peculiar and rapid urbanization processes experienced (19). The emergence and legalization of flat ownership by the enactment of Law on Flat Ownership in 1965 was due to the urgent housing needs in urban areas, which if would have not been developed (together with unauthorized housing/squatter housing- gecekondu), homelessness could be the alternative urban phenomenon in Turkey. Renting out of privately owned dwelling units and thus development of a private rented 
20. HUD's rental housing assistance for low-income families and individuals fall into three basic categories:Conventional public housing, Housing Choice Vouchers and Privately owned assisted housing (Accessed online report "Characteristics of HUDAssisted Renters and Their Units in 2003" of US Department of Housing and Urban Development Office of Policy Development and Research through the link: http://www. huduser.org/publications/pubasst/hud asst rent.html (accessed on 21.09.2008).

21. This performance is especially relevant when compared to construction statistics of several developed countries as well. See Balamir $(1996,336)$ for further discussion. sector was made possible. The flat ownership law legalized an already developed form of tenure relations in urban areas. Renting in Turkey thus corresponds only to private renting in the absence of public renting. All rented stock is privately owned by households (Balamir, 1999). High ratios in private renting could be realized firstly because high home ownership ratios (ambitions) facilitated private renting to emerge and secondly because, public renting as an alternative tenure form was never favored by authorities. This type of renting pattern can be considered to be too liberal since even in countries like USA where market forces dominate almost all relations in housing; there is more administrative control over the private rented sector than the Turkish case. Further, in the USA, the owners of the private rented sector are not necessarily the private households who rent out their dwellings according to personal modalities. Additionally, the private renting is not alone even in the USA; it is supported with public housing where possible (20).

As a result of flat ownership, private contractors in Turkey were able to generate a well developed housing industry in terms of number of units annually produced. In subsequent three years (1993-1995) for instance, more than half a million units were annually produced (Sarığlu et al., 2007) and as Balamir (1982) argues, the number of units exceeded the need for housing.

High population increases together with migration to urban areas increased the needs for housing especially in the urban areas, and the gap was filled by housing provision of private entrepreneurs. The number of buildings constructed points out an impressive performance of those private entrepreneurs resulting in substantial growth of the housing stock. Turkey was able to generate a well developed housing industry in terms of number of units annually produced. In subsequent three years (19931995) for instance, more than half a million units were annually produced (Sarığlu, et.al. 2007) and as Balamir (1982) argues, the number of units exceeded the need for housing. It is relevant to note that none of these were public investments. It is also significant to note that the construction statistics of Turkey only comprise the authorized buildings; therefore the actual figures are higher than the given ones (21).

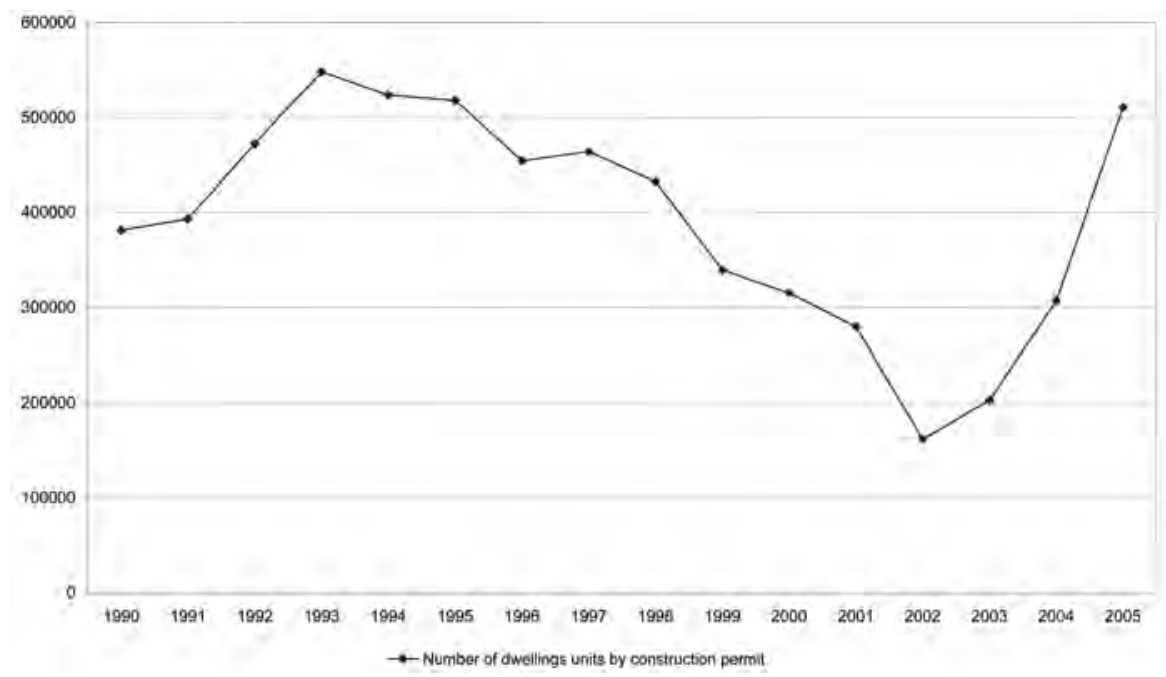

Figure 1. Change in the housing stock 2005). (TURKSTAT (2005) 2003 Building Construction Statistics). 
Figure 2. Total number of dwelling units and households in urban areas, Turkey (19502005)

(Updated from Balamir, 2002, 338 (23)).
22. For the period of 1955-1995, see Balamir, $2002,67$.

23. Updated from Balamir 1996. Number of urban Hhs in 2005 and 2006 are estimates of Household Budget Surveys (HBS) obtained from Hh Consumption Expenditure Database (2002-06). It is crucial to underline that available figures on urban dwelling units cover only the authorised part of the housing stock since it is derived from construction permit statistics, whereas number of urban Hhs contains population accommodated both in the authorised and unauthorised part of the stock as census data and HBS estimates cover all Hhs.

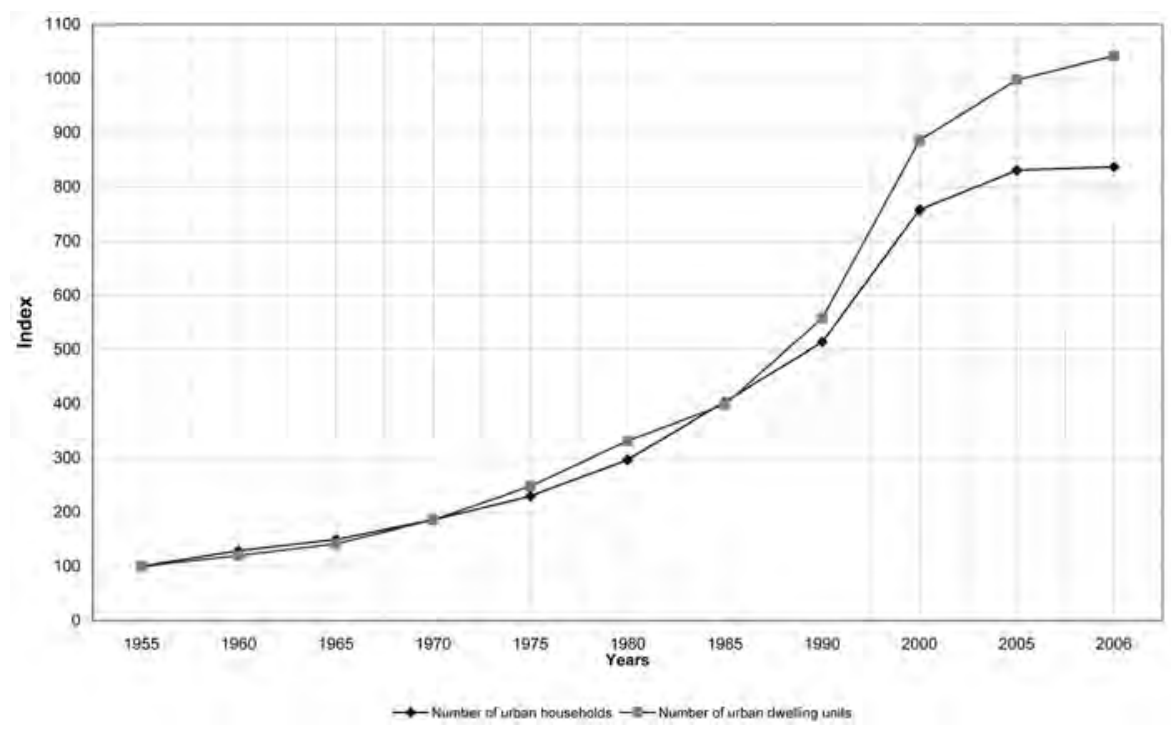

These figures are significant to evaluate regarding the number of households: when examined with respect to the number of households (Figure 2), the growth of the housing stock proves to provide an average of $20 \%$ surplus housing in short periods, disregarding the spatial variances. This is more than the ratio of 3-4 \% which could be accepted as the needed surplus for mobility in a housing stock (Balamir, 2002, 68).

The majority of building constructions has been apartment blocks since it also dominates the total housing construction in Turkey (22). When compared with the number of households, this performance reveals that there is now excess supply of housing in urban Turkey.

Increases in the number of Hhs and dwelling units have been parallel to each other until 1990s after which number of dwellings increased at higher rates. This led to formation of a surplus of housing. Beginning from 2005, however, opposite trends are observed in the increase rates which points out the gap between number of households and dwelling units will widen.

It was argued that housing stock characteristics do not adequately match the needs of households which may be argued to lower the residential satisfaction of households as well as efficient use of the housing stock by either under utilization or over crowding (Sarığlu, 2007, Sarığlu et al. 2007). Therefore, the growth of housing stock was not sufficient to meet all the need and could not prevent the formation of "unauthorized housinggecekondu" which appeared to be the only way for especially low income population who newly migrated to big cities. Unauthorized housing was also developed as high rise blocks in Turkey. The latter involved employment of professional builders and more substantial investments than in gecekondu (Balamir, 1996a, 338).

Within these processes, as the households, entrepreneurs, construction firms developed methods to meet the housing demand; administrations continued their passive roles in Turkey. That solutions are already being developed by actors in the housing system was interpreted by administrations as a satisfactory rationale to go on with the same attitude rather than to take the responsibility. The two major exceptions can be considered to be the foundation of Housing Development Administration in 1984 which constructed 43,145 dwelling units and financed construction 
24. http://www.toki.gov.tr/ozet.asp (accessed on 23.05.2008).

25. http://www.toki.gov.tr/ozet.asp (accessed on 20.09.2008).
Figure 3. Gecekondu Areas in outskirts of Ankara (Sarığlu, 2007).

Figure 4. Flat Ownership in Ankara (Sarığlu, 2007). of 900,000 dwelling units (24) until 2003, and the enactment of law on housing finance in 2007 (25).

In addition to owner occupation ambitions and relevant share of private renting, the housing in Turkey has a significant third component: unauthorized housing. Mainly in metropolitan cities, low income groups had developed illegal processes like "gecekondu (built overnight)" which can be defined simply by appropriation of land without the permission of the right holders, and building rapid and cheap housing on it violating all development controls. Especially in the outskirts of larger cities, deprived of infrastructural facilities, at most 2 storey gecekondu became the prevalent housing type. Gecekondu, in the beginning, was undertaken by low income migrants. Governments ignored this illegal practice for years, firstly because households, who were really in desperate need of accommodation had resorted to it as a remedy, and secondly because this process masked the inadequacy of governments in housing. With the enactment of subsequent gecekondu amnesties gecekondu could be legalized and turned out to be a primitive housing provision process, organized by profit seeking groups. The dominant understanding that "if a household waits sufficient time living in a gecekondu, there is always a positive rate of return in monetary terms and the title is got in the end". This process lost its innocence in time and became a major problem which governments could not solve. The problems related to gecekondu can fall out of the scope of this paper since they involve identity issues, environmental and spatial quality, infrastructural inadequacies, poverty issues etc. However, this paper will include gecekond $u$ from the perspective of becoming home owners; it is accepted as a distinct tenure type in the sense that it provides its occupant the use of the dwelling like an owner, without paying rent, but for an uncertain period. The end of the process is not known; after the demolishment, the occupant may either become an authorized owner or a seldom homeless.

\section{b. The Netherlands}

In the Netherlands, housing has traditionally been considered as a 'need' which should be undertaken by the state rather than an issue which could be solved within the market mechanisms. Its social housing stock has been one of the largest ones in Europe: $45 \%$ of the all housing stock is social housing (WBO, 2002). Positions of two basic tenure types, namely owner occupancy and renting, are quite supportive to each other when compared to Turkey. Further, since the country did not experience rapid
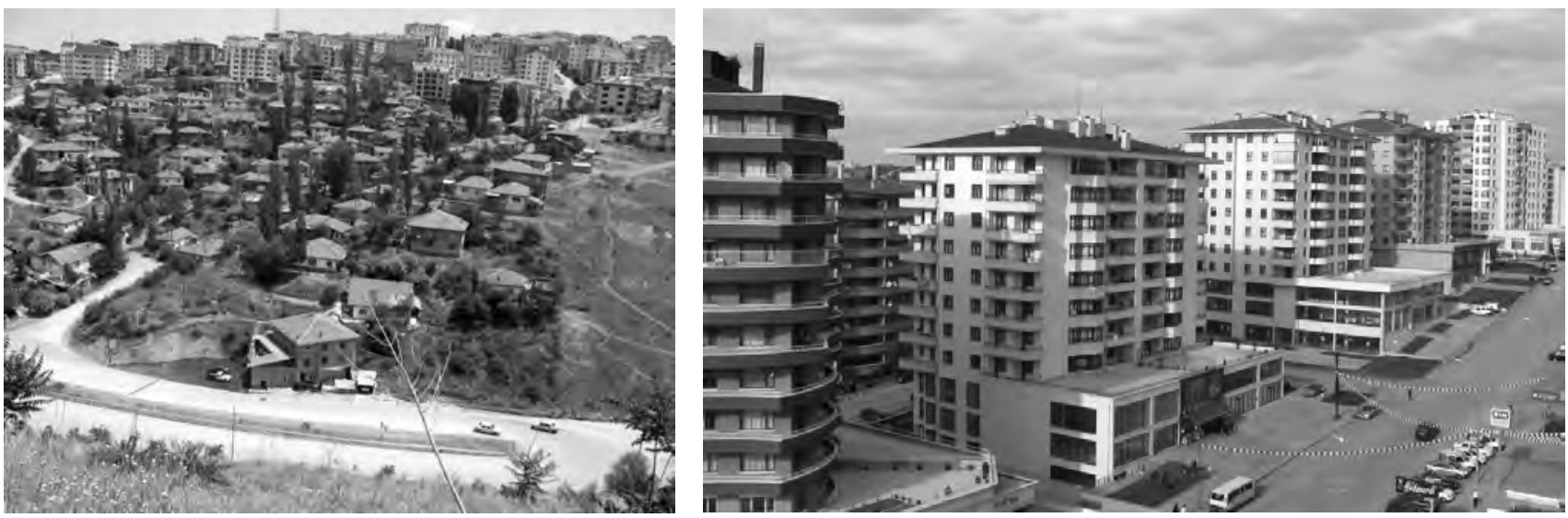
26. http:/ / international.vrom.nl/pagina.

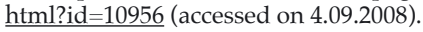

27. http://international.vrom.nl/pagina. html?id=10961 (accessed on 4.09,2008).
Table 3. Tenure type and home ownership rates in the Netherlands, 1947-2007 (x 1000). Vrom, 1997, Statline (http:// statline.cbs.nl/StatWeb/publication/ ?DM=SLEN\&PA $=7413$ eng\&D1 $=19$ $20,22,26,29 \& \mathrm{D} 2=0 \& \mathrm{D} 3=12-20 \& \mathrm{LA}=\mathrm{EN} \&$ $\mathrm{HDR}=\mathrm{T}, \mathrm{G} 2 \& \mathrm{STB}=\mathrm{G} 1 \& \mathrm{VW}=\mathrm{T})$ (C) Statistics Netherlands, Den Haag/Heerlen 20.1.2009. urbanization and unauthorized housing like the Turkish one, housing policies could be generated and implemented succesfully. The relatively good macro economic conditions and lower inflation ratios did not lead home ownership ambitions. The system could offer alternatives for low income groups (public renting; 35-37 \%) (26), for unstable but moderate income groups (private renting $10 \%)(27)$, and for high income and stable households (owner occupancy $56 \%$ ) (WBO, 2002). Supported by mortgage finance opportunities, owner occupancy was never a matter of sole investment.

The country has been characterized with low ratio of home ownership until very recently. In 1947, just after the WWII, the ratio of owner occupation was only $28 \%$. With gradually increases the ratio reached $41 \%$ in 1977 and $52 \%$ in 2000. Although there have been several policies of promoting home ownership, the public rental sector is still significant in the Netherlands especially in big cities such as Amsterdam and Rotterdam where the ratios of renting are respectively $78,7 \%$ and $71,8 \%$ (WBO, 2002) (Sarığlu, et. al, 2007).

In the Netherlands, after the Second World War, there was a substantial housing need. The shortage was estimated to be of 300,000 dwelling units according to the 1947 Census of population. The situation was worsened as a result of the rapid growth in the number of households. Therefore, 'quality' was not a primary concern for the state at that time, since the urgent need was for a shelter (Aedes, 2003).

Newly built dwellings of the period were, due to the price constraints, small, typical duplexes and low rise flats with shared stairwells (Boelhouwer, 2002). In the post war period, up to 1970s, the rented sector dominated the newly built dwellings in the Netherlands (Figure 3).

The growth of the housing stock has a slow pace in terms of number of units produced when compared to Turkey (Figure 4). The gap between number of households and number of dwelling units furthermore is

\begin{tabular}{|l|l|l|l|l|}
\hline Years & $\begin{array}{l}\text { Number of } \\
\text { owner occupied } \\
\text { dwellings }\end{array}$ & $\begin{array}{l}\text { Number } \\
\text { of rented } \\
\text { dwellings }\end{array}$ & $\begin{array}{l}\text { Total number of } \\
\text { dwellings }\end{array}$ & $\begin{array}{l}\text { Home } \\
\text { ownership } \\
\text { rate }\end{array}$ \\
\hline 1947 & 595,3 & 1530,7 & 2126,0 & \\
\hline 1956 & 744,4 & 1822,6 & 2567,0 & 28 \\
\hline 1964 & 1044,5 & 2027,5 & 3072,0 & 29 \\
\hline 1971 & 1325,5 & 2461,6 & 3787,0 & 34 \\
\hline 1977 & 1836,8 & 2643,2 & 4480,0 & 35 \\
\hline 1982 & 2081,9 & 2875,1 & 4957,0 & 41 \\
\hline 1986 & 2315,1 & 3068,9 & 5384,0 & 42 \\
\hline 1990 & 2610,9 & 3191,1 & 5802,0 & 43 \\
\hline 1994 & 2937,1 & 3181,9 & 6119,0 & 45 \\
\hline 1995 & 2973,6 & 3221,4 & 6195,0 & 48 \\
\hline 1996 & 3078,4 & 3204,1 & 6282,5 & 48 \\
\hline 1998 & 3180,0 & 3180,0 & 6360,0 & 49 \\
\hline 2000 & 3382,6 & 3122,4 & 6505,0 & 51 \\
\hline 2002 & 3578,5 & 3048,4 & 6626,9 & 52 \\
\hline 2004 & 3694,0 & 3081,5 & 6775,5 & 54 \\
\hline 2007 & 3895,4 & 3147,8 & 7043,2 & 55 \\
\hline & & & \\
\hline
\end{tabular}


Figure 5. Change in the number of newly built dwellings with reference to tenure, The Netherlands (1956-2004) (Vrom, 1997 and www.statline.nl.
Figure 6. Total number of dwelling units and households, The Netherlands (1947-2007) (Vrom, 1997). (28)http:// statline.cbs.nl/StatWeb/publication/ ?DM $=$ SLEN\&PA $=37556$ ENG\&D1 $=45 \& D 2=$ $\underline{48,57,65,72,78,83,87,91,95-97,99,101,103,105,}$ $108 \& \mathrm{LA}=\mathrm{EN} \& \mathrm{HDR}=\mathrm{G} 1 \& \mathrm{STB}=\mathrm{T} \& \mathrm{VW}=\mathrm{T}$

(C) Statistics Netherlands, Den Haag/ Heerlen 11.03.2009 http: / / statline. cbs.nl/StatWeb/publication/ ?DM=SLEN\&PA=7413eng\&D1=19-20,22,26, $29 \& \mathrm{D} 2=0 \& \mathrm{D} 3=12-20 \& \mathrm{LA}=\mathrm{EN} \& \mathrm{HDR}=\mathrm{T}, \mathrm{G} 2 \&$ $\mathrm{STB}=\mathrm{G} 1 \& \mathrm{VW}=\mathrm{T}$ (C) Statistics The Netherlands, Den Haag/Heerlen 11.03.2009
28. The scale of Figure 4 is deliberately enlarged to 1100 on the y axis to in order to make it comparable with Figure 2. It is significant to note that Turkish one represents only urban Hhs and dwelling units considering the comparatively lower ratio of urbanizaiton in the country. Figure 3.6 covers the whole housing stock and households in the Netherlands.

29. http://statline.cbs.

$\mathrm{nl} /$ StatWeb/publication/ ?VW $=\mathrm{T} \& \mathrm{DM}=\mathrm{SLEN} \& \mathrm{PA}=7413 \mathrm{eng} \& \mathrm{D} 1=0$ $2 \& \mathrm{D} 2=0-12 \& \mathrm{HD}=090324-$

$1205 \& \mathrm{LA}=\mathrm{EN} \& \mathrm{HDR}=\mathrm{T} \& \mathrm{STB}=\mathrm{G} 1$ (accessed on 24.03.2009).
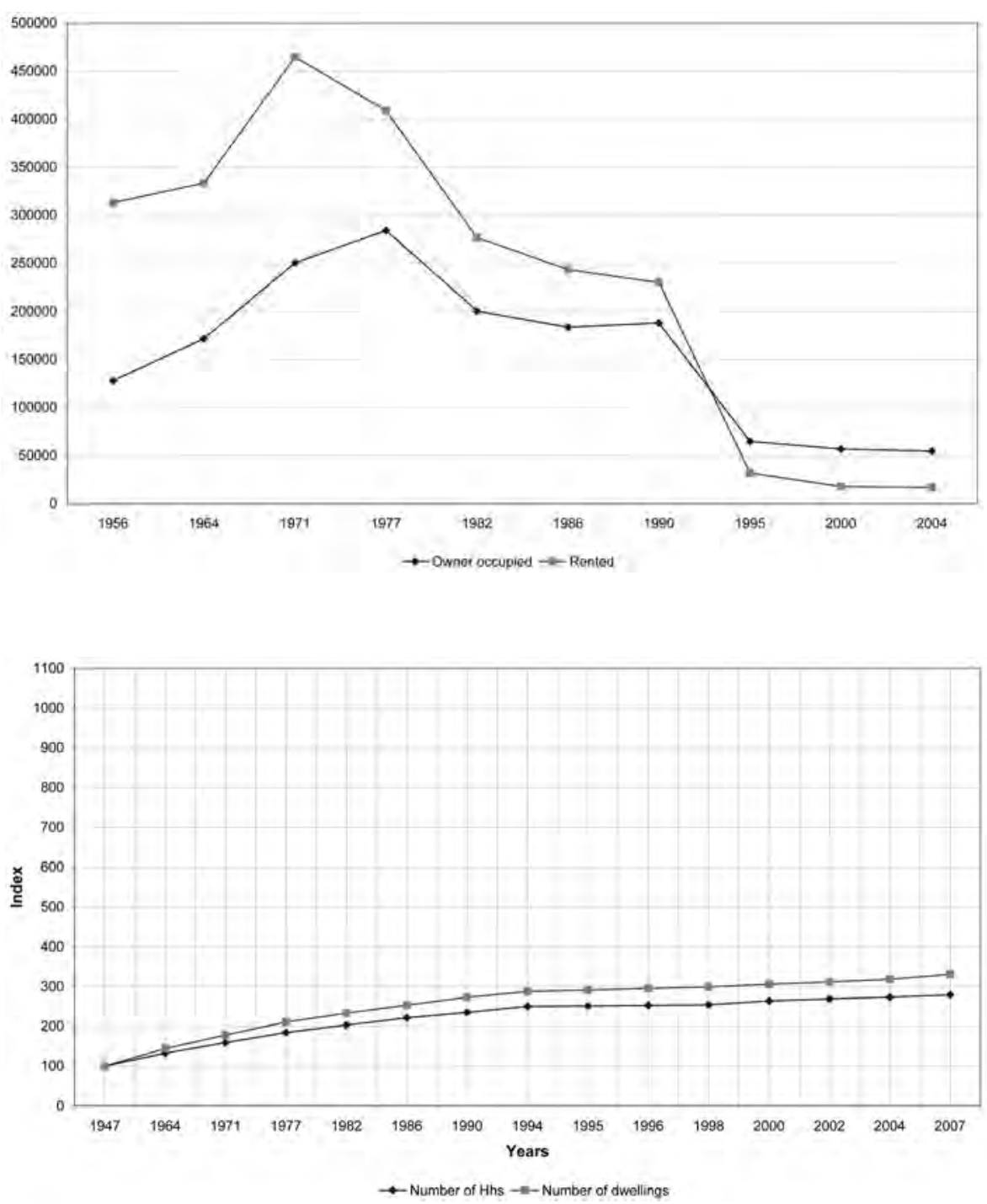

significantly smaller. This represents a relatively better matching between housing stock and households in the Dutch case.

The comparison of the two housing stocks reveals that there are decreases and increases in the number of units annually produced, depending on the socio-economic circumstances of the countries. Due to the large total population difference, the total number of dwelling units is $12,214,000$ in Turkey (2006) and 7,043,212 (29) in the Netherlands in 2008.

As the figures reveal, the primary role of the government in housing continued until 1990s. By the beginning of 1980s, there were liberalization movements in Europe; yet, the major changes in Dutch housing system could begin only after the 1990s. Unlike other Western countries, total expenditure of government in housing kept increasing in the period 19701990 (Boelhouwer and Van der Heijden; 1992). With the introduction of 'Housing in the nineties', in 1989, the role of central governments was lessened via decentralization of several responsibilities to municipalities and housing associations (Dileman and van Kempen, 1994). This white paper pointed more liabilities to landlords and consumers in a more 
30. www.minvrom.nl (accessed in September 2008).

31. www.minvrom.nl (accessed in June 2008).

32. Sarığlu (2007).

33. http://stats.oecd.org/WBOS/Index. aspx?DatasetCode $=$ CSP2008 (accessed on 18.03.2009, acquired by selecting the two countries). business like environment. Additionally, the rules and regulations were simplified which emphasized the desire of the government for deregulation in housing (30). It was afterwards that the role of government in housing began questioning. The ongoing concept of merit good understanding for housing lost its validity (Boelhouwer, 2002). It was no more necessary for the central government to play its primary role in the housing market (Vrom, 1997). The first reason in this policy change was that policy goal in subsidizing housing made governments take heavy financial burdens which would no more be economically defended (Vrom, 1997). Secondly, housing has become a problem of 'quality' rather than 'quantity'. To put in other words, the policies implemented for almost 50 years had achieved the goal and eliminated the problem of housing shortage. The stock has almost increased 3.5 times after the war from a total of 2,126,000 dwelling units to $6,626,900$ units (Table 3).

In the beginning of 2000s, Housing in the 21st Century was introduced. This housing memorandum emphasized the freedom of choice of individuals in their housing without damaging the social justice (31). Yet, it was highly criticized by scholars who denoted that housing memorandum is not coherent in saying that "A greater say to the households is given" (Priemus, (2001a); Boelhouwer, 2002). These scholars believe that there is still not a tenure-neutral housing policy in the Netherlands. According to them, when the income is high, governments favor owner occupation and when the income is lower renters are over-supported. This means that rather than the choice of the households about their housing, it is the government that already makes the choice from the beginning.

Yet, it can be stated that recent Dutch housing policy mainly rests on respecting the individualization of society and their changing housing preferences, promotion of owner occupation and increasing urban quality. Private entrepreneurs are supported to get more responsibilities and more attention is devoted to increase green and blue in urban areas (Heins, 2005). In the Netherlands, public rental housing has been the distinctive feature of housing. Like Turkey, rural ownership ratio is higher than urban ratio: 71 $\%$ in rural areas, whereas only $53 \%$ in urban Netherlands (WBO, 2002).

\section{HOUSING FINANCE IN THE TWO COUNTRIES (32)}

In macro economic terms, the Netherlands is a more developed country when compared to Turkey. The Dutch GDP per capita figures have been almost 5 times higher than the Turkish. From US \$4,084 in 1970, Dutch GDP per capita increased to US \$36,548 in 2006. Whereas GDP per capita of Turkey (US $\$ 8,766$ ) in 2006 is almost equal to Dutch GDP per capita (US $\$ 8,246)$ in 1978 (33).

This economic advantage made it possible to establish a powerful mortgage system in the Netherlands. Dutch mortgage is not a system based only on arranging the relations between bank-household, and the mortgage on the dwelling. It has supportive institutions that orient the operations of the actors and interfere when necessary like the National Mortgage Guarantee (Nationale Hypotheek Garantie, NHG). There are buyers, housing corporations, banks, mortgage advisers, NHG, real estate agents involved in this process.

The Dutch mortgage system is quite developed responding to household demands and wishes. Banks have different interest rates, loan terms and schemes. Generally speaking, the primary pre-requisite for getting 
Table 4. Inflation and CPI for the Netherlands, (1900-2007).

(c) Statistics Netherlands, Den Haag/Heerlen 11.12.2008.

\begin{tabular}{|l|l|l|}
\hline Subjects & Consumer Price Index & Inflation \\
\hline Periods & $1900=100$ & $\%$ \\
\hline 1900 & 100.0 & \\
\hline 1910 & 112.1 & 2.8 \\
\hline 1920 & 225.8 & 10.4 \\
\hline 1930 & 154.5 & -3.8 \\
\hline 1940 & 152.9 & 14.7 \\
\hline 1950 & 312.4 & 9.1 \\
\hline 1960 & 414.4 & 2.5 \\
\hline 1970 & 628.1 & 4.4 \\
\hline 1980 & 1274.5 & 6.5 \\
\hline 1990 & 1627.3 & 2.5 \\
\hline 2000 & 2082.9 & 2.5 \\
\hline 2001 & 2178.5 & 4.6 \\
\hline 2002 & 2251.6 & 3.4 \\
\hline 2003 & 2299.7 & 2.1 \\
\hline 2004 & 2326.9 & 1.2 \\
\hline 2005 & 2366.7 & 1.7 \\
\hline 2006 & 2393.9 & 1.1 \\
\hline 2007 & 2432.4 & 1.6 \\
\hline
\end{tabular}

mortgage is to have an employment contract. Several mortgages include insurance premiums. The mortgage alternatives are so diversified that it takes quite a time to decide on which type of mortgage is the best for the household. Thus, there are also mortgage advisers who help the households in this decision. The contract about mortgage is generally for 30 years, longer than the inflationary Turkish case where the prevalent term is only 10 years. When households face financial difficulties, NHG may be consulted for financial assistance. This type of an institution does not exist in the Turkish mortgage system.

This type of a system was possible not only because of administrative policies towards housing but also due to more stable macro conditions and low inflation rates. As the Table 4 demonstrates, in the Netherlands inflation rates never exceeded $15 \%$ even during or after the Second World War.

However, this strong and diversified mortgage system was also criticized on the grounds that the policy of tax deduction of mortgage interest rates could not lead affordable access to owner-occupation rather than that the result in the housing market was increase in house price inflation (Grius, 2008) (34). Anyhow, the Dutch mortgage system offers more options to households and open paths for OO when compared to the Turkish case where only recently the law on housing finance has been enacted. The above review on the Dutch mortgage system reveals that in the Netherlands, in addition to public renting opportunities offerred, there is a supporting financial system for owner occupation as well. In Turkey, however, due to the high inflation and interest rates experienced, it was impossible to develop a housing finance system for decades.

Between 1990 and 2006, average annual inflation rate was 57 \% for Turkey, whereas for the same period the figure was only $2 \%$ for the Netherlands (35). Figures indicate that both countries experienced radically distinct macro economic conditions which favoured a mortgage system in the 
Table 5. Inflation and Consumer Price Index (CPI) for Turkey (1965-2004).

* With respect to same month of the previous year.

${ }^{* *}$ With respect to annual averages.

Source: http://evds.tcmb.gov.tr/cbt.html (accessed on 05.06..2009).

35. http: / / data.un.org/Data.aspx?q=inflat ion\&d=SOWC\&f=inID\%3a79 (accessed on 31.12.2008)

\begin{tabular}{|l|l|l|l|}
\hline & Inflation rate* $^{*}$ & CPI $^{* *}$ & \\
\hline 1965 & 3,57 & 148,8 & $1958=100$ \\
\hline 1970 & 8,43 & 115,1 & $1968=100$ \\
\hline 1975 & 19,55 & 251,3 & $1968=100$ \\
\hline 1980 & 84,87 & 1886,1 & $1968=100$ \\
\hline 1985 & 52,77 & 1159,6 & $1978-1979=100$ \\
\hline 1990 & 60,00 & 454,6 & $1987=100$ \\
\hline 1995 & 130,60 & 8511,7 & $1987=100$ \\
\hline 2000 & 68,90 & 2970,4 & $1994=100$ \\
\hline 2004 & 16,20 & 9212,1 & $1994=100$ \\
\hline
\end{tabular}

In Turkey, banks did offer credits for the purchase of a house. These were not of efficient to use. While European households were able to become home owners by getting mortgage credits, entry to home ownership profiles have been observed distinctly in Turkey. The absence of mortgage system has been a major issue in Turkish housing system for decades. Due to the high inflation and interest rates experienced, it was impossible to develop a housing finance system. Banks did offer credits for the purchase of house however, these were not efficient to use. While European households were able to become home owners by getting mortgage credits, distinct entry to home ownership profiles have been observed in Turkey. As the study of CMB (Capital Markets Board of Turkey) (2005) points out, of all the home owners, only $3 \%$ used credits from financial institutions for their purchases in Turkey. Rather, in the absence of mortgage law, the parental resources used to be more significant in buying a home in Turkey. In March 2007, finally, Law on Housing Finance was enacted. This law is actually a compilation of several items from related laws. With this law, in addition to banks, leasing companies and consumer finance companies (non-bank institutions) which are found eligible to operate in housing finance by the Banking Regulation and Supervision Agency (BRSA) can also lend money to households, both variable and fixed rates are possible in the purchase of house (Sarığlu, 2007).

Turkish mortgage law appears to be a compilation of related items from different laws for an ordinary "consumer good": housing. Disregarding social aspects, home is just considered as a good which is sold in the market. The positive effects will possibly be that firstly, it will help to decrease unauthorized houses by compulsory incorporation of occupancy permit and secondly, statutory obligation for disaster insurance will decrease the number of un-insured houses. The law does not have priorities for lower income groups therefore whether further penetration to the lower end will be possible is a question mark. The effects of this law on the market can be evaluated in time, yet it is expected that future adjustments will be inevitable for a more effective housing finance system (Sarığlu, 2007).

\section{EHOPS}

\section{a. EHOPs in Turkey}

Unsatisfactory housing policies in Turkey were substituted by real market processes resulting in dominance of home ownership. In the absence of a housing finance system, households could become home owners in a set of profiles. These profiles represent the dynamics of home ownership experienced in Turkey and help to understand how households could access the required capital sources in becoming home owners. In order 
Table 6. Key figures for EHOP Inmates*, in comparison with other Hh types.

* The figures in this Table are calculated only for owner occupier 3 generation households but not for 3 generation Hhs in rented dwellings since only the former would be an EHOP (and called as inmate). to develop more efficient housing policies, the following groups and associated processes should be examined as a valuable policy instrument. Although there are theoretical profiles generalized in entry to home ownership (EHO) cross countries, these profiles do differ considerably depending on the socio-cultural and historical processes, political and demographic patterns. Considering that becoming a home owner is one of the biggest purchases of a household, it is strongly related with access to capital. In HDA's (Housing Development Administration of Turkey) study $(2006,62)$, it was stated that, personal savings is the most frequent source of capital by $76 \%$ share in all housing finance. Within this group, $61.9 \%$ of owner occupiers who did not use credits from financial institutions could become owner occupier by their own savings; $7.2 \%$ by selling previous property; $5.7 \%$ by selling other property and $1.2 \%$ with savings from abroad. Figures reveal that, the absence of a finance system made development of alternative paths to access capital. Therefore, the dynamics of becoming home owner resulted in several profiles which can be grouped as follows:

Inmates: The demographic attributes of the Turkish population indicate that, $15.7 \%$ of the urban and $19.3 \%$ of the whole population are 3 generation households (HBS, 2003). When considered together with the tenure type, of the all owner occupier Hhs in urban Turkey, $18.5 \%$ is 3 generation Hhs (HBS, 2003). This is a high ratio indicating that, for those households, housing problem is solved by combining financial resources of grandparents, parents and children in the same dwelling unit. The absence of housing finance systems together with inadequacy of administrations in housing, made households live together in the same dwelling unit in order to decrease costs for 'housing'. In Coleman and Garssen's (2002) terminology, this attitude may be accepted as inclination to economize on space by living with relatives. Thus, this $\mathrm{EHO}$ profile is considered to lead to overcrowding in most cases. This frequent way of living is called as inmating in this study referring to 3 generation Hhs owner occupiers.

Occupancy rate (36) (persons per room) figure for inmates is the highest among all household types is 1.61 .

In terms of personal space available, measured by unit square meter per person, the group of inmates is found to have overcrowding mostly because inmates have the highest household size. The group of inmates has the highest averages also for dwelling size and number of rooms.

Of all inmates (owner 3 generation Hhs), $49.5 \%$ lives in "house" type dwellings. This is higher not only than those of nucleic families and single parents which have $34.9 \%$ and $37.1 \%$ ratios respectively, but also than the frequency ratio of "house" dwelling type in urban Turkey; $35.04 \%$ (HBS,

\begin{tabular}{|l|l|l|l|l|l|l|}
\hline & $\begin{array}{l}\text { Average } \\
\text { Hh Size } \\
\text { (A) }\end{array}$ & $\begin{array}{l}\text { Average } \\
\text { number } \\
\text { of rooms } \\
\text { (B) }\end{array}$ & $\begin{array}{l}\text { Average } \\
\text { dwelling } \\
\text { size (C) }\end{array}$ & $\begin{array}{l}\text { Persons per } \\
\text { room (A/B) }\end{array}$ & $\begin{array}{l}\text { Unit sq. m. per } \\
\text { person (C/A) }\end{array}$ & $\begin{array}{l}\text { Dominant Dwelling } \\
\text { type }\end{array}$ \\
\hline Inmates & 5.80 & 3.60 & 105.43 & 1,61 & 18,17 & $\begin{array}{l}\text { House } \\
(49.5 \%)\end{array}$ \\
\hline $\begin{array}{l}\text { Single Parent } \\
\text { Hhs }\end{array}$ & 2.09 & 3.33 & 98.42 & 0,62 & 47,09 & Apartment $(59.3 \%)$ \\
\hline Nucleic Hhs & 3.85 & 3.49 & 103.55 & 1,10 & 26,89 & Apartment $(61.9 \%)$ \\
\hline Other & 2.57 & 3.57 & 99.88 & 0,71 & 38,86 & Apartment $(65.3 \%)$ \\
\hline
\end{tabular}


36. Occupancy rate is defined as the number of people dwelling in a house per habitable room (kitchens and bathrooms are not counted). A rate of one person per room is taken as acceptable, more than one person per room represents overcrowding. occupancy rate" (A Dictionary of Geography. Susan Mayhew. Oxford University Press, 2004. Oxford Reference Online. Oxford University Press.

(http:/ / www.oxfordreference.com/views/ ENTRY.html?subview=Main\&entry $=\mathrm{t} 15$ $\underline{\mathrm{e} 2207)}$
2003). The group of inmates is the only household type which mostly lives in houses but not apartments (the most frequent dwelling type; $61.53 \%$ ) in urban Turkey. Thus inmating may indicate an indirect "rural" habit of living.

Inheritors, parental donations and family borrowing: High inflation figures and unstable macro economic conditions made investment value of home ownership significant for many households in Turkey. In the absence of a housing finance system specifically aiming at entry to home ownership, many households could become home owners due to inheritance. Parents' insistent efforts to purchase a house are not only for investment purposes but also for decreasing future housing ambiguities of children.

Becoming a home owner increases saving capacity of a household and makes it easier to buy the second or third ones. In this process, once the household could become a multi-owner, then earning rental income could provide extra saving capacity as well. In the following periods, the children could benefit from parents' ownership. As Kayıket (2003:107-8) denotes, in Turkey;

"Most of the beneficiaries are 30 and more aged who already are homeowners This means that the inherited properties may find itself into the market and have impacts on property markets..... It also seems that the third generation successors (mostly grandchildren) may benefit from the inherited property more than their parents (second generation successors), since the age level of inheriting is high".

Related to "inheritors", there is another remark to be made: the group, "Not owner but not paying rent" with a $6.44 \%$ share (2003) (Table 2), consists of households who live in the houses owned by relatives or parents. In this sense, they are the most probable future owners of those dwellings (Sarığlu, 2007a). Even not inmates literally, living in parents' or relatives' housing is a culturally and socially accepted way of becoming home owners in Turkey. This EHO profile could be accepted to be "donation" or "gift" rather than direct inheritance yet it also occurs due to parents' or relatives' already assets.

In addition to inheritors and parental donations, there are those households who borrow from family members, mostly parents, in order to become owner occupiers. The ratio of households who borrowed from family is found to be $10.3 \%$ (HA, 2006, 62) in Turkey revealing the significance of family relations in $\mathrm{EHO}$. By inheritance, donations or borrowing, this path in EHO turned out to be one of the significant EHOPs in Turkey.

Transfers relying on private debts: The absence of an efficient housing finance system in Turkey was recruited by private and informal debt relations between relatives and acquaintances as well. Considering the high ratio of home ownership in the absence of a housing finance system for decades, scale of private relations in entry to home ownership in Turkey could be believed to be high. In a study of HDA (2006:62), the amount of private debts in $\mathrm{EHO}$ was denoted to be $12.3 \%$.

Direct purchasers (with existing assets and fortunes-savings): The ability to buy with own savings and fortunes in Turkey was possible for a number of households. In order to have sufficient wealth to purchase a house directly, previous income history of the parents, already available wealth and saving capacity could be relevant. 
In urban Turkey, $6.3 \%$ of the all households denoted that they own another dwelling unit other than they inhabit (HBS, 2003). If not vacant, and not used for seasonal purposes, these units could be rented out for rental income or donated to children making them a member of 'households who are not owners but who do not pay rent' (Table 2). The ratio of Hhs who own another dwelling other than they inhabit could be even higher in reality as the private rental sector is owned only by private Hhs and comprise $28 \%$ of urban housing stock in Turkey. The owners of these rental units must have another dwelling to live in as well. Such asset rich parents and/or relatives could make the next generation "direct purchasers". This profile also represents the relevance of "investment value" of home ownership. If a household is already an owner occupier in the beginning of his housing career, then savings could be possible and it becomes easier to make further fortunes.

Alternatively, direct purchasing could be possible for households with higher saving capacities. In HDA's study (2006, 62), $61.9 \%$ of owner occupiers who did not use credits, were found to use personal savings in purchase of dwellings.

Purchasers via Housing Development Administration (HDA): Housing Development Administration of Turkey could offer several options spatially distributed all over the country especially for the first time buyers and low income groups. Until 2002, almost 950.000 dwelling units were financed by credit facilities and 43.145 units were constructed by HDA (37). This type of policy opened paths at least for increasing the amount of savings and making households owners, even not owner occupiers.

Due to the Justice and Development Party policies towards "housing mobilization", 328, 300 dwelling units were completed in the whole country. For low income groups, 72.065 dwelling units were constructed within 2003-2008 and for the programs of 'Gecekondu Transformation', 'Disaster Housing' and 'Agriculture Village', another 46.418 dwelling units were built in the same period (38). Although the figures quantitatively represent a bulk in the housing stock, it can not be argued that affordability problem in Turkey has been overcome. Of the newly completed stock of HDA, only $21 \%$ aimed at low income groups. Thus, even with the help of HDA, becoming owner occupiers has been possible primarily for middle or high income groups.

However, many of HDA's programs were envisaged as a way of taking on debt which would lead at least to 'home ownership' (39) although not to immediate 'owner occupation' especially in the former periods. Recent HDA policies put emphasize on provision of housing to households living in that particular city. The absence of housing finance system in Turkey could be overcome by becoming a home owner although not owner occupier. In doing so, households do not primarily consider the proper household-housing matching rather consider this profile as a way of saving capital which could be utilized for owner occupation in future.

37. http://www.toki.gov.tr/ozet.asp (accessed on 20.09.2008).

38. http://www.toki.gov.tr/ozet.asp (accessed on 23.05.2008).

39. Home ownership, in here, does not refer to owner occupation, unlike the rest of the study.
Transfers with market debt programs: Due to high inflation and unstable macro economic conditions, in Turkey, a successful housing finance system could not been developed until 2007. Until that time, available market debt programs could offer credits only for shorter terms and with high interest rates. This made households save as much as possible and get credits for the residual amounts. Only used in this manner, the market debt systems could be beneficial and contributory. Recently enacted law on housing 
finance system which extended the maturity of the credit longer and could offer lower interest rates due to favorable macro-economy, still needs further arrangements, yet it will most probably increase home ownership rates (Sarığlu, 2007b). Thus, the share and significance of this entry to home ownership profile is expected to increase in the future.

In 2004, the total amount of housing credits was only 5\%o of GNP, a very low figure when compared to US (53\%), EU average (39\%) and even Middle East countries (1-22\%) (HA, 2006:63). However, Turkey is assumed to be a significant emerging market in terms of real estate in the near future, accelerated by the enactment of mortgage law. In Housing Finance and Turkey III, a conference held by GYODER (The Association of Real Estate Investment Companies) and CMB (Capital Markets Board of Turkey), it was affirmed that until 2015, the amount of mortgage credits will reach to $\$ 88.4$ billion, comprising $15 \%$ of GNP (Gürlesel, 2006).

Gecekondu (unauthorized housing): The absence of intervention in market provision of housing led to the development of unauthorized housing in various forms including gecekondu, especially by the poor for whom the market forces could not generate effective solutions. Gecekondu is a major problem especially in bigger cities of Turkey. In Ankara, for instance, of all households $19.5 \%$ live in gecekondus covering 8306 ha (40) of the city. This is a significant indicator revealing that affordability has been the most relevant issue in Turkey. Considering that gecekondu provides at least an indefinite period of use and an ambiguous possession of a dwelling unit which may possibly end up with ownership, the process has been followed by households who recently migrated to big cities. Due to several amnesties, significant number of gecekondu (Photo 1) dwellers became legal home owners in apartment units under flat ownership (Photo 2).

Cannot afford: Other than these profiles, there is also household who can not afford home ownership. These households could be those for whom authorized procedures could not provide access to ownership either due to low saving capacity or low income of households. In a previous study carried with 1994 HICES (41) data set, of all renters of the urban sample, $30.2 \%$ of Hhs were identified to have affordability problems in Turkey (Taylan, 2003).

The ratio of each category in EHO may be distinct for various spatial units though it is expected that in urban areas as a whole, the significance of informal and private debt relations together with inheritors and parental donations would be utmost. These 8 groups also vary in terms of the perception and meaning of home ownership. Becoming a home owner may have different meanings for these 8 groups not only in economic but also for social and cultural terms. For lower income groups, for instance, it is expected that home ownership is more of a financial security and status issue. Whereas, for higher income groups, home ownership may be

40. Ankara Metropolitan Municipality, Development and City Planning Department (2006), 1/25000 scale Ankara 2023 master plan studies, p. 326.

41. HICES stands for Household Income and Consumption Expenditures Survey of TURKSTAT, a previous form of Household Budget Survey (HBS) which is used in this study. considered more of a natural consequence of the housing careers. The latter is similar to European housing career typology in general terms.

The 8 groups are assumed to differ in terms of general household features. The grouping is already done by considering these differences implicitly: e.g. the gecekondu group consists mostly of low income households who recently migrated to urban areas. However, displaying those variances explicitly could be problematic since not all of these groups can be identified from the same data set. 


\section{b. EHOPs in the Netherlands}

Dutch housing system is developed in such a way that positions of two basic tenure types, namely 'owner occupancy' and 'renting', are quite supportive to each other when compared to Turkish case. The system subsidizes renting for small, younger or older and lower income groups who are relatively instable. As a result of extensive central housing policies applied for decades, renting still persists as one of the significant tenure types in the country. The system itself made this inevitable; it is cheaper, physically quite good and spatially avaliable in urban areas. Public renting in the Netherlands not only could compete with private renting but also with owner occupancy as well. The socially accepted way of living in public renting made this tenure type relevant in many aspects. For older householders (aged $65+$ ) renting is the prevaling tenure type (WBO, 2002). Further, considering that the country did not experience rapid urbanization and unauthorized housing like the Turkish one, the housing policies could be generated and implemented succesfully. The relatively good macro economic conditions and lower inflation ratios did not lead home ownership ambitions. the system could offer alternatives for low income groups (public renting), unstable but moderate income groups (private renting), and high income and stable households (owner occupancy). The significance of inheritors and parantal donations in the Turkish case, would not happen to be frequent in the Dutch case due to already avaliable mortgage system. Similarly, inmating would not be expected to form a relevant EHOP in the Netherlands, because of the differences in household formation processes. As Coleman and Garssen $(2002,454)$ denote, the three generation households are very exceptional in the Netherlands revealing that the Dutch seem to be disinclined to economize on space by living with their relatives, or indeed with anyone else. Therefore, for the Dutch case, EHO profiles can be grouped as follows:

Transfers with market debt programs: The share and significance of this EHOP is higher than any other EHO in the Netherlands. Of the all owner occupiers in the urban parts of the Netherlands, $75.7 \%$ used one mortgage, $13 \%$ used more than one in order to become owner occupier (Table 7). Recalling that in Turkey of all the home owners, only $3 \%$ used credits from financial institutions for their purchases (CMB, 2005); Dutch figures reveal the significance of the mortgage system in the Netherlands. This reveals that housing system and policies strongly influence EHOPs.

Through the Home ownership Guarantee Fund, almost 50\% of dwellings bought that fall within the EUR 265,000 limit are financed by "National Mortgage Guarantee (NHG). On average, the fund provides 75,000 guarantees a year. Generally NHG buyers are younger than 35, often double-income couples or single persons, buy existing dwellings more and more, and increasingly opt for an apartment (42).

Table 7. Mortgages used by owner occupiers, Urban Netherlands. Source: Processed from (WBO, 2002).

\begin{tabular}{|l|l|l|}
\hline Mortgage & Frequency & Valid Percent \\
\hline One & 22244 & 75.7 \\
\hline More & 3824 & 13.0 \\
\hline None & 3319 & 11.3 \\
\hline Total & 29387 & 100.0 \\
\hline System Missing & 4437 & \\
\hline Total & 33824 & \\
\hline
\end{tabular}


42. http:// www.nhg.nl/ content/ content. aspx?id=0\&cid=8 (accesed on 23.09.2008).

43. http:// www.expatica.com/nl/housing. html (16.09.2008) Life on a Dutch Barge (25.04.2008)

44. http:// www.expatica.com/nl/housing. html (16.09.2008) Life on a Dutch Barge (25.04.2008)
Table 8. Mortgages used by owner occupiers, Urban Netherlands. Source: Processed from (WBO, 2002).
Transfers without mortgage: At column 'Valid percentage', $11.3 \%$ of the current owner occupiers did not use mortgage in the Netherlands in order to purchase their current dwellings (Table 4). Therefore, the shares of profiles like "inheritors and parental donations", 'transfers relying on private debts' and 'direct purchasers' must add up to $11.3 \%$ in the Netherlands who did not use mortgage in becoming owner occupiers. These are grouped under one profile for the Dutch case: transfers without mortgage.

The WBO does not provide specific information to enable categorization transfers without mortgage. However, further interpretations can be made: In the WBO, there are 2604 households who were owner occupiers in previous dwellings and now also owner occupiers in current dwellings. Of this group, only $4.4 \%$ did not use mortgage in purchase of current dwellings (Table 8). Therefore, this group represents households who, most probably, used their previous real estate and assets in order to become owner occupiers.

Boat (Waterwonen): An alternative Dutch way of solving housing problem is households living in boats and caravans. Considering the extensive canal systems, "living on water" turned out to be a Dutch way of housing. Living costs in boats involve mostly monthly mooring cost which is about EUR 200 depending on the size of the boat, water taxes and everyday practical costs which may add up to EUR 1000-3000 a year (43). Living on boats is subject to quite developed rules and regulations; for instance, the distance between boats must be $2 \mathrm{~m}$ and the distance from a bridge must be $7 \mathrm{~m}(44)$.

In the WBO data set, only $0.2 \%$ of all owner occupiers live in boats and caravans. This figure does not indicate that it is a significant EHOP and yet, living on boats exists as an alternative tenure form. This EHOP is pretty different from other EHOPs since it does not involve the land related (like being fixed, durable etc) attractiveness of owner occupation. However, it is included in the study since it is a distinct way which households developed and then administrations put rules to regulate in the Netherlands. Like other EHOPs, this one also stems from the socio-economic, spatial and cultural circumstances. As 'gecekondu' type of development could not be expected in the Netherlands, living in boats could not be anticipated for Turkish context. Living in barges is socially and culturally accepted in the Netherlands.

Owner occupation through 'sale of rented dwellings': As a part of recent OO promotion, the administrations aimed to increase the home ownership rate through the sale of public rented dwellings. In WoOn 2006, 5.6\% of all owner occupiers denoted that they were the previous renter of those particular dwellings. In such moves to owner occupation, the move does not bring extra space to the owner and yet, due to personal reinvestments in the dwelling, the physical quality could be improved. The aim was

\begin{tabular}{|l|l|l|l|l|}
\hline Previous and Current Tenure & Mortgage & Frequency & Percentage & Valid Percentage \\
\hline Owner occupier & One & 2161 & 83.0 & 86.2 \\
\hline & More & 236 & 9.1 & 9.4 \\
\hline & None & 111 & 4.3 & 4.4 \\
\hline & Total & 2508 & 96.3 & 100.0 \\
\hline & Missing & 96 & 3.7 & - \\
\hline & Total & 2604 & 100.0 & - \\
\hline
\end{tabular}


Figure 7. "Waterwonen" in Groningen (Sarıoğlu, 2008).

45.http:/ / www.vrom.nl/pagina. html?id=37439 (accessed on 12.02.2009).

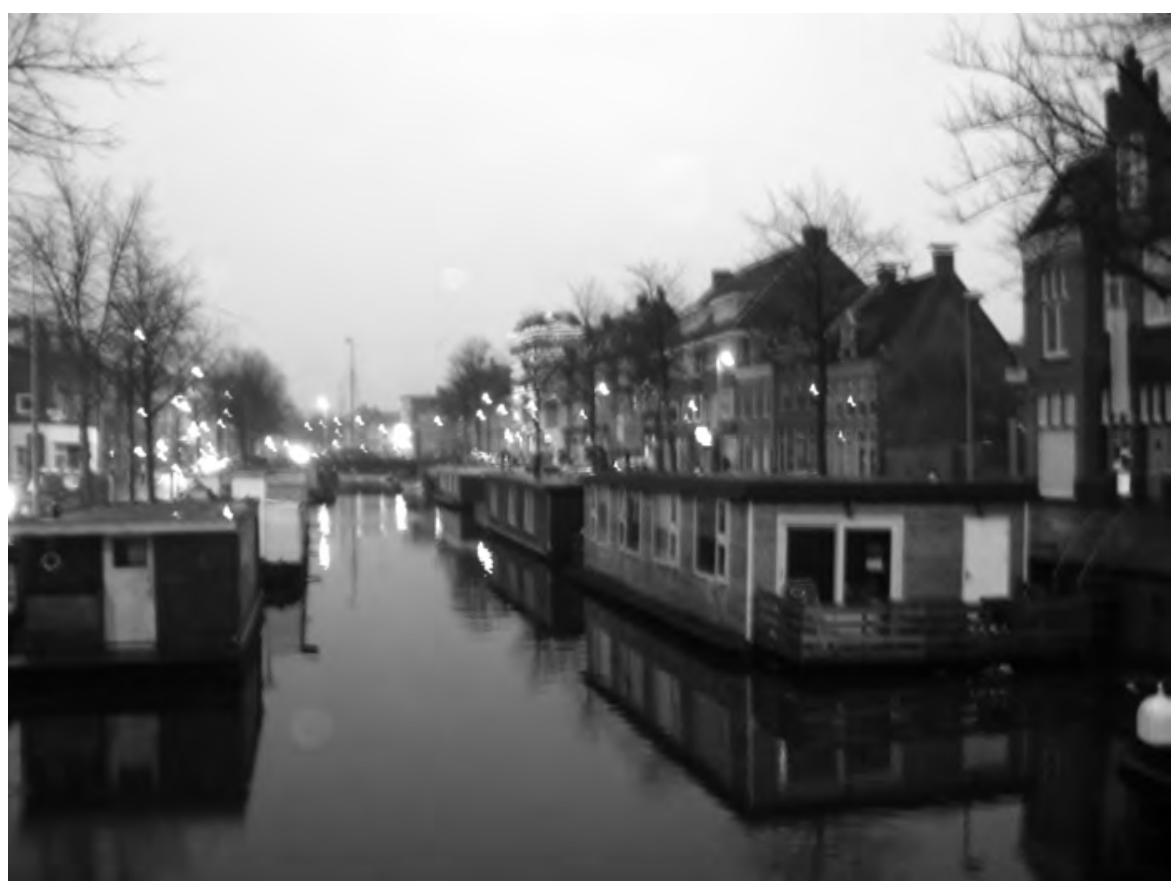

to sale of 500, 000 dwelling units until 2010 and yet only only 108,200 dwelling units were sold until 2006 (45).

Squatting: It can not be argued that squatting has been a major problem in the Netherlands when compared to Turkey. It is not in the same manner either: Rather than squatting in unoccupied lands and construction of selfbuilt dwelling units, in the Dutch case, squatting is living in unoccupied dwelling units in already built up areas of cities. It is not a priority issue and yet there are concerns to forbid. Policies against squatting are based on prevention of un-occupied stock which is not desired from the perspective of neighborhood quality as well (46). Further, squatting in the Netherlands is more a way of solving the shelter problem and not leads to getting the property title and becoming owner occupiers as in the Turkish case.

Cannot afford: In addition to these profiles, there is household who can not afford home ownership in the Netherlands. Although affordability is still a significant issue in many countries, with increasing policies towards the promotion of home ownership and housing funds, specific groups are identified as target groups. In the Netherlands, there is a specific fund developed as a part of housing funds. "Fund for Starters" aims at activating municipalities to develop a policy to solve present problems of "starters" (first-time buyers) in the housing market to find a dwelling of their own (47).

In Rabobank's $(2008,3)$ recent study $(48)$, a slight deterioration of affordability is expected for 2008, followed by stabilization at a low level in 2009 which will make it even more difficult for first-time buyers to gain a foothold on the property ladder. This stems mainly from increases in both money and capital market interest rates which had a negative impact on the affordability of purchasing a house in the Netherlands. 
47. http://international.vrom.nl/pagina. html?id=10962 (accessed in September 2008).

48. Report of Rabobank "Dutch housing Market Quarterly, August 2008", at http:// overons.rabobank.com/content/images/ KwaWo-2008q2ENG tcm64-83182.pdf

(accessed on 23.03.2009).

49. Purchase year in HBS is recorded as the year that household purchased the dwelling OR the year that the title deed was transformed to the household. If, the dwelling belongs to parents of any of the members of the household, then the year since household has been living there is recorded. Therefore, there are cases where purchase year is earlier than the birth year of household head. These cases represent the inheritance and inmating processes in Turkey. Since a HHh can not become a home owner at ages like $-51,2$ or 0 , when calculating average $\mathrm{EHO}$ age, these cases were excluded. Additionally, considering the separate household formation process, $\mathrm{EHO}$ ages less than 18 are further excluded. As a result, the number of cases decreased from 11859 to 11026 . Without doing this it would not be possible to calculate the average $\mathrm{EHO}$ age and $\mathrm{EHO}$ age groups. For the Netherlands, as well, a similar process is followed. The number of cases for EHO-age decreased from 27282 to 27501 in the end. EHOI sample is also same with EHO sample for the two countries.

50. To give an example, say Hh has been living there for 30 years then he/ she has been living there since $1973(2003-30=1973)$. Consider that the dwelling was purchased in 1967. In this case, $\mathrm{EHO}$ is (2003-30) $-1967=6$. In HBS duration in that dwelling is provided as a variable (30 years in the example), thus it is subtracted from data year of 2003 in order to get the exact year when the household began living there. In WBO, not the duration but the exact year that the household began living in that dwelling is referred (1967 in the example).

\section{c. Householder age in EHO: A comparison for current owner occupiers in urban Turkey and the Netherlands}

In the absence of retrospective data on $\mathrm{Hh}$-housing characteristics, $\mathrm{HHh}$ age provides significant explanation for EHO. Thus, the analysis on EHO is deepened by calculating the average EHO age for the two countries. The available data sets in both countries have the variables of "purchase year of that particular dwelling" (49) and HHh age. By a simple computation of subtraction;

(Purchase year) $-($ Birth year of $\mathrm{HHh})=\mathrm{Hh}^{\prime}$ s EHO_age

age of HHh in becoming owner occupier in that dwelling can be calculated. This age gives however at what age the HHh became the owner of that particular dwelling, ie., it does not necessarily imply first owner occupation. Yet, this figure can be accepted to be a relevant comparative indicator for $\mathrm{EHO}$ age especially if the $\mathrm{HHh}$ is young.

In order to have a better explanation, from the two data sets another variable is recoded: $\mathrm{EHO}(50)$. This is the value calculated by;

Year of Data- (Duration in that dwelling) - (Purchase year) $=\mathrm{EHO}$

EHO is grouped into three in order to get an index: EHOI:

If the EHOI value equals to 0 , then this indicates owner occupation; the household purchased the dwelling and began living there at the same time.

If the EHOI is + (higher than 0; such as in the example given in footnote), then it means that Hh was already owner of that dwelling yet $\mathrm{s} /$ he began living in there later than the actual ownership date. In other words, s/ he is home owner since 1967 but owner occupier since 1973. This could happen, most probably, if the dwelling bought was under construction in the purchase date. Thus, households have to wait until the dwelling is completed. Alternatively, the deed is transformed to the household in advance, and yet moving may be possible after some time. This may happen when for instance parents transform the deed to their children but continue living in the dwelling mentioned as a part of usufruct right.

If the EHOI is - (lower than 0), then it means that Hh was already an inmate in that dwelling or not a separate household at the time, most probably living with his/ her parents. In the process he/she became the owner occupier via inheritance or donation.

To give some descriptive numbers of EHO_age and EHOI for Turkey and the Netherlands:

In urban Turkey, of the EHOI sample, $60.8 \%$ bought housing units and began living in those units at the same time. This group of households may fall into the EHOPs of Transfers relying on private debts, Direct purchasers (with own savings and fortunes), Transfers with market debt program and / or inheritance. $22.5 \%$ of the EHOI sample, however, most probably bought from the new stock and had to wait until the dwellings were completed. This group represents also the waiting time for home owners in order to become owner occupiers. In Turkey, this is 3.93 years. In other 


\begin{tabular}{|l|l|l|}
\hline & Turkey & The Netherlands \\
\hline Average HHh age in EHO* & 36.79 & 34.95 \\
\hline Min EHO_age (due to filter ) & 18 & 18 \\
\hline Max EHO_age & 92 & 89 \\
\hline Ave. EHO + & 3.93 & 2.42 \\
\hline Ave. EHO - & -4.03 & -13.01 \\
\hline Number of Hhs of owner occupation & $7,213 \mathrm{Hh}$ & $21,553 \mathrm{Hh}$ \\
(EHOI=0) & $(60.8 \%$ of EHO sample) & $(78.7 \%$ of EHOI sample) \\
& $(39.5 \%$ of whole sample) & $(34.1 \%$ of whole sample) \\
\hline EHOI=+ & $4,118 \mathrm{Hh}$ & $4,739 \mathrm{Hh}$ \\
& $(22.5 \%$ of EHO sample $)$ & $(7.5 \%$ of EHOI sample) \\
& $(34.7 \%$ of whole sample $)$ & $(17.2 \%$ of whole sample $)$ \\
\hline EHOI= - & $528 \mathrm{Hh}$ & $1,209 \mathrm{Hh}$ \\
& $(2.9 \%$ of EHO sample) & $(1.9 \%$ of EHOI sample) \\
& $(4.5 \%$ of whole sample) & $(4.4 \%$ of whole sample $)$ \\
\hline
\end{tabular}

Table 9. Descriptives for EHO_age and EHOI in Turkey and the Netherlands.

* This does not necessarily be the first owner occupation age. Average, minimum and maximum EHO_age are calculated within the EHO sample which consists of only owners from which missing cases and EHOage less than 0 cases are subtracted. 6,419 missing cases in HBS refer to non owner occupiers, comprising 35.1\%. When EHO_ Age $\leq 0$ are eliminated as well, sample size reduces to 11,859 Hhs for Turkey EHO_Age. In the Netherlands case, 35,732 missing cases which refer to non owner-occupiers, comprise $56.5 \%$ of WBO. Together with $\mathrm{EHO}-$ Age $\leq 0$ subtraction the size reduces to 27,501282 in the Dutch case. However, in order to calculate age groups and age averages further deductions are carried (EHO ages less than 18): the sample size reduced to 11,026 Hhs for Turkey and to 27, 282 Hhs for the Netherlands. words, households on average wait 3.93 years, as home owners until they become owner occupiers. Thirdly, $2.9 \%$ of the owner occupiers in Turkey were initially inmates and yet finally became the owner occupiers in the process. They begin housing careers as owner occupiers prior than other households. Households within this group become owner occupiers as soon as they form their separate households.

In the Netherlands, as well, the "EHOI: 0" group is the most significant one. By $78.7 \%$ ratio, this mostly indicates the transfers with mortgage. $7.5 \%$ of the EHOI sample, however, has to wait some time in order to become owner occupiers. On average, this is 2.42 years, lower than Turkey, meaning that Dutch households spend 2.42 years as home owners, but non owner occupiers, before they move to their own dwellings (or the title is transferred to them). Lastly, $1.9 \%$ of the Dutch owner occupiers were initially inmates or 'not a separate households' (for the Dutch context) and yet, finally became owner occupiers in the process. In this case, household is already owner occupier, before forming his seperate household.

The average EHO-ages for both countries are close to each other: 36.79 for Turkey and 34.95 for the Netherlands. EHO-Age group frequencies, demonstrated in Figure 5, are also similar; Households who became owner occupiers younger than 20 age cohort (Eho_age) for instance is $2.6 \%$ in Turkey and $1.8 \%$ in the Netherlands. This similarity is also valid for 31-40 Eho-Age groups: $34.8 \%$ and $33.8 \%$ respectively.

A major difference is observed for 21-30 EHO_age group. While $40.2 \%$ of current Dutch owner occupiers entered $\mathrm{OO}$ when they were 21-30 age years old, in Turkey, this ratio is $29 \%$. For Turkey, the most significant age category is 31-40 meaning that of the all current owner occupiers in Turkey, $34.8 \%$ became owner occupiers when they were $31-40$, on average ten years later than the Dutch households. This finding supports the previous discussions of "late ownership" for Turkey (Sarığlu, 2000; 2003).

Table 10 indicates that of the all current owner occupiers in Turkey, only $3.2 \%$ have become owner occupier before HHh age was 20 years old. $34.8 \%$ of the current owner occupiers' HHh was 31-40 age years old when they moved to OO. Dutch figures demonstrate earlier EHO when compared to Turkey: Of the all current owner occupiers in the Netherlands, $40.2 \%$ became owners when HHh age was between 21 and 30. Results are noteworthy when compared with the current HHh age frequency 
Figure 8. EHO age Group frequencies for urban Turkey (2003) and the Netherlands (2002)

Processed from (HBS, 2003) and (WBO, 2002).

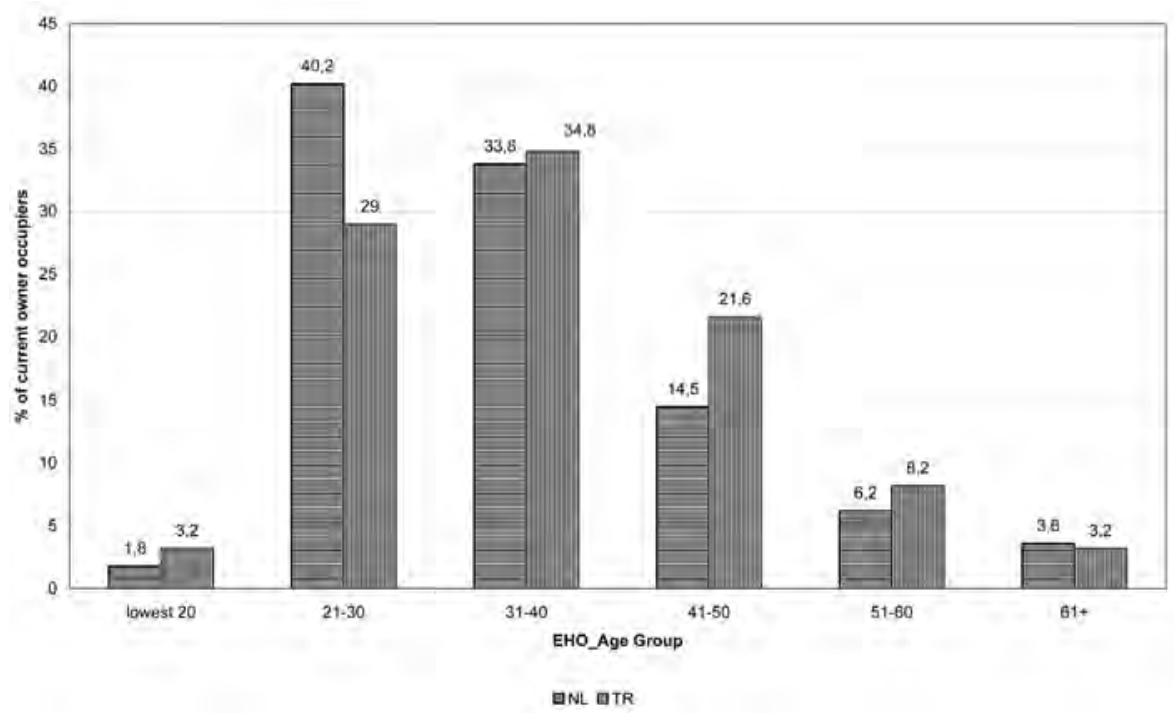

distributions. Although Turkey is characterized by a younger population, due to the late $\mathrm{Hh}$ formation process, ratio of $\mathrm{Hhs}$ in the 21-30 age group is relatively small $(4.8 \%$ ) when compared to the Netherlands $(13.7 \%)$.

A final remark could be made depending on the average age of marriages in the two countries (26.1 in Turkey, 36.3 in the Netherlands for males). Assume that each man at 26 year old in Turkey will constitute separate Hh. This means 6.410 .891 (51) new Hhs will be formed based on only marriage and 6.410.891 dwellings will be needed accordingly in the next 10 years. The demand of these new Hhs could be smaller units, like 2 room units. Yet, considering the Eho_age identified for Turkey, they will become owner occupiers in ten years. EHO flows were found to bring extra space in $65 \%$ of the moves in Turkey (Ankara) (Sarığlu, 2009). This means within ten years period, more than half of these Hhs will move to larger dwellings. This could require completion of 6.4 million units of which 4.167.079 dwellings are more than 2 rooms in 10 years.

For the Netherlands, a similar discussion could also be made. Here, rather than the age of marriage, age of 18 is assumed to be the initial $\mathrm{Hh}$ formation age. Accordingly, in 10 years 2.000 .000 (52) new Hhs could be formed as the age of persons reaches 18, requiring that amount of smaller units in the stock. EHO age identified is 34 for the Netherlands, thus within 16 years they would possible realize EHO move. EHO in the Netherlands
Table 10. Frequency and \% of EHO age, and $\%$ of HHh age, Turkey 2003, The Netherlands 2002.

Source: Processed from (WBO, 2002) and (HBS 2003). HHh age and EHo age younger than 18 are omitted for both countries.

${ }^{*} \mathrm{HHh}$ age percentages represent whole urban samples, not only owner occupiers which is the case for EHO age frequency and percentages.

\begin{tabular}{|l|l|l|l|l|l|l|}
\hline & \multicolumn{2}{|l|}{ Turkey } & Netherlands & \multicolumn{2}{l|}{} \\
\hline & $\begin{array}{l}\text { Frequency } \\
\text { of EHO age }\end{array}$ & $\begin{array}{l}\text { Valid } \\
\text { Percent of } \\
\text { EHO Age }\end{array}$ & $\begin{array}{l}\text { Valid } \\
\text { Percentage of } \\
\text { HHh Age* }\end{array}$ & $\begin{array}{l}\text { Frequency of } \\
\text { EHO age }\end{array}$ & $\begin{array}{l}\text { Valid } \\
\text { Percent of } \\
\text { EHO age }\end{array}$ & $\begin{array}{l}\text { Valid } \\
\text { Percentage of } \\
\text { HHh Age* }\end{array}$ \\
\hline $\begin{array}{l}\text { lowest through } 20 \\
(18-20)\end{array}$ & 357 & 3,2 &, 0 & 490 & 1,8 &, 2 \\
\hline $21-30$ & 3195 & 29,0 & 4,8 & 10963 & 40,2 & 13,7 \\
\hline $31-40$ & 3835 & 34,8 & 21,2 & 9222 & 33,8 & 28,2 \\
\hline $41-50$ & 2387 & 21,6 & 29,2 & 3943 & 14,5 & 23,8 \\
\hline $51-60$ & 902 & 8,2 & 22,8 & 1680 & 6,2 & 17,9 \\
\hline highest through 61 & 350 & 3,2 & 22,0 & 984 & 3,6 & 16,2 \\
\hline Total & 11026 & 100,0 & 100,0 & 27282 & 100,0 & 100,0 \\
\hline
\end{tabular}


52. Calculated from: http://www.cbs.nl/en$\mathrm{GB} / \mathrm{menu} /$ themas/bevolking/cijfers/extra/ piramide-fx.htm.
(ROA) is found to bring extra space in all cases (100\%) (Sarığlu, 2009), therefore, 2 million larger units will be needed within 16 years.

Assume the opposite figures were valid for the two countries (like, 18 age for Hh formation in Turkey and 26 for the Netherlands). In that case, in Turkey 6.508.090 new Hhs would be formed and until they become 34, they would become owner occupiers by moving to larger dwellings: 6.508.090 dwellings of two rooms at first, eventually larger 6.508.090 owner occupied dwellings in 16 years (almost 2.5 million more dwellings would be required when compared to the initial example). In the Netherlands, 1.000 .700 two room dwellings at first would be necessary, in ten years until they become owner occupiers more room or larger 650.455 owner occupied units would be demanded (compare with 2 million units of the first example).

\section{DISCUSSION AND CONCLUSION}

Depending on the descriptive and historical examination of the cases, EHO profiles were developed in order to reveal how households have become owner occupiers in Turkey and the Netherlands. For Turkey EHOPs identified are inmates; inheritors, parental donations and family borrowing; transfers relying on private debts; direct purchasers (with own savings and fortunes); purchasers via Housing Administration (HA); transfers with market debt program; gecekondu (unauthorized housing) and cannot afford.

EHOPs defined for Turkey mostly reflect the absence of state support in housing provision. They are generally individualistic efforts developed by private relations. Only exceptions are EHOPs of purchasers via Housing Administration (HA) and transfers with market debt program. In the Netherlands, EHOPs identified are transfers with market debt programs; transfers without mortgage; boat (waterwonen); owner occupation through buying the social rented dwelling; squatting and cannot afford. These EHOPs strongly reflect the effects of strong government regulation implemented extensively in the country.

Entry to home-ownership, like many other housing issues, is strongly related to socio-economic circumstances of the countries and the housing policies developed. When EHOPs are determined for countries, it becomes easy, firstly to understand what the system has led to, and secondly, to develop/modify policies in accordance.

Inmates in Turkey, for instance, stems mainly from the Turkish household formation process in which living together with parents and even grandparents is socially and culturally accepted. And yet, it is also because there was not an extensive housing finance system, until 2007, which offers credits for long periods of time. Therefore, households attempted to decrease housing costs by living together in larger households leading to overcrowding. When the situation is comprehended in this manner, administrations could be more successful in developing housing policies. In the instance of inmates, the problem of overcrowding could be solved either by bettering of housing finance system (like making inmates a special and priority group) or offering them larger dwellings units, say with more rooms, where overcrowding would no longer be a problem. While the former policy modification would enable more privatization/ individualization to households, the latter would solve the problem by keeping the current household size and living habits. 
In the Dutch case, EHOP of transfers with mortgages is found to be the strongest, since in a country where housing has been evaluated as one of the most significant intervention domains of administrations, comprehensive policies including housing finance would certainly be provided. Not surprisingly, the Dutch administrations, though favored renting more in the immediate post-war period, developed also a mortgage system answering demands of those who want to become owner occupiers. The alternatives in the system are complementary to each other and households are not forced to find other alternatives to access capital, unlike the Turkish case.

The EHO Index developed and the figures represented are mostly simple efforts to categorize the entry to home ownership process in the two countries. A better comprehension can be acquired when the findings are examined with reference to household head age frequencies and by utilizing retro respective data sets. However, the study could be accepted to highlight that housing system and demographic differences the two countries have relevant repercussions in the outcomes. From another perspective, this can be annotated like, when "entry to home ownership" is taken as a single coherent issue in a housing system, policies could be developed more efficiently and many other entities of housing systems (like household features and housing stock attributes) could be manipulated since they are implicitly involved in $\mathrm{EHO}$ process.

\section{ABBREVIATIONS}

CBS: $\quad$ Central Statistics Bureau (Centraal Bureau voor de Statistiek)

CMB: $\quad$ Capital Markets Board of Turkey (Sermaye Piyasası Kurulu)

EHO: $\quad$ Entry to Home ownership

EHOI: $\quad$ Entry to home ownership index

EHOP: $\quad$ Entry to home ownership profile

Hh: Household

HBS: $\quad$ Household Budget Survey

HDA: $\quad$ Housing Development Administration of Turkey

(Toplu Konut İdaresi Başkanlığı)

GYODER: The Association of Real Estate Investment Companies

(Gayrmmenkul Yatırım Ortaklı̆̆ı Derneği)

NHG: $\quad$ National Mortgage Guarentee

(Nationalle Hypotheek Guarantee)

TURKSTAT: State Institute of Statistics (Türkiye İstatistik Kurumu)

VROM: $\quad$ Ministry of Housing, Spatial Planning and the

Environment

Milieubeheer)

(Het ministerie van Volkshuisvesting, Ruimtelijke Ordening en

WBO:

Housing Demand Survey (Woningbehoefte Onderzoek)

\section{REFERENCES}

AEDES (2003) Dutch Social Housing in a Nutshell, Hilversum. (Online access: http:/ / www.aedesnet.nl/binaries/downloads/2007/08/ dutchsocialhousinginanutshell2007.pdf)

BALAMIR, M. (1975) Kat Mülkiyeti ve Kentleşmemiz (Flat Ownership and Urbanization in Turkey), ODTÜ Mimarlık Fakültesi Dergisi, (1/2) 295318. 
BALAMİR, M. (1982) Urbanization, Urban Processes, and Urban Structure, in The First Urbanization Congress of Turkey (V1) ed. by Y. Gülöksüz, METU Department of City and Regional Planning, Ankara; 13-54.

BALAMİR, M. (1996) Making Cities of Apartment Blocks, Transformation of the Built Environment in Turkey by means of Reorganizations in Property Rights, in Housing and Settlement in Anatolia, Tarih Vakfl, İstanbul.

BALAMİR, M. (1999) Formation of the Private Rental Sector in Turkey, Netherlands Journal of Housing and the Built Environment (14:4) 385-402.

BALAMİ, M. (2002) Necessary Revisions in the Planning System in Turkey with Respect to the New Agenda of Urban Regeneration, Yapı Dergisi (253) 66-70.

BOELHOUWER, P. J. (2002) Trends in Dutch Housing Policy and the shifting position of the social Rented Sector, Urban Studies (39:2) 219235.

BOELHOUWER, P. J. and VAN DER HEIJDEN, H.M.H. (1992) Housing systems in Europe: Part I. A comparative study of housing policy (Housing and urban policy studies 1), Delft, University Press, Delft.

CLARK, W. A. V., DEURLO, M. C., DILEMAN F. M.(1997) Entry to Homeownership in Germany: Some Comparisons with the United States, Urban Studies (34:1) 7-19.

COLEMAN, D. AND GARSSEN, J. (2002) The Netherlands: paradigm or exception in Western Europe's demography? Demographic Research, V: 7, Article 12. www.demograpic-research.org.

DIELEMAN, F. M., AND EVERAERS, P. C.J. (1994) From renting to owning: Life course and housing market circumstances, Housing Studies (9:1) 11-26.

DIELEMAN, F. M., VAN KEMPEN, R. (1994) The mismatch of housing costs and income in Dutch housing, Journal of Housing and the Built Environment (9:2) 159-72.

FEIJTEN, P. and MULDER, C. H.(2002) The Timing of Household Events and Housing Events in the Netherlands: A Longitudinal Perspective, Housing Studies (17:5) 773-92.

HBS (2003) TURKSTAT Household Budget Survey, raw data.

HDA (2006) Türkiye'de Konut Sektörü ve TOKI'nin Konut Üretimindeki Yeri, Research Series, No: 2, Yapı Endüstri Merkezi, Ankara.

HDA (2008) Konut Uygulamaları Özeti.

HEINS, I. (2005) Lecture notes, Introduction to Housing, University of Groningen.

GRIUS, V. (2008) The Netherlands, in Cowans, J. and Maclennan, D., eds., Visions for Social Housing: International Perspectives, The Smith Institute; 75-84.

GÜRLESEL, C.F. (2006) Türkiye'de Konut İhtiyacı ve Talebine Bağlı Konut Finansman Sisteminin Gelişme Potansiyeli ve Ülke Ekonomisine Katkisı 2015, Paper presented at Housing Finance and Turkey Conference III, İstanbul. 
KAYIKET, A. (2003) The process of intergenerational transmission of housing wealth, unpublished master thesis, METU Department of City and Regional Planning, Ankara.

MEGBOLUGBE I. F., LINNEMAN P.D. (1993) Home Ownership, Urban Studies, (30:4/5) 659-82.

MULDER, C. H. and WAGNER, M. (1998) First Time Home-ownership in the family life course: A West German-Dutch Comparison, Urban Studies (35:4) 687-713.

PRIEMUS, H. (2001a) A new housing policy for the Netherlands (20002010): A mixed bag, Journal of Housing and the Built Environment (16:34) 319-32.

PRIEMUS, H. (2001b) Poverty and housing in the Netherlands, Housing Studies (16:3) 277-89.

SARIOĞLU, G.P. (2007) Turkish Housing system: history and current debates in comparison with several EU countries, Paper presented at ENHR Working Group Comparative Housing Policy Seminar, 20/21 Nisan, April 2007, Dublin.

SARIOĞLU, G.P., BALAMIR, M., PELLENBARG, P. H. and TERPSTRA, P.R.A (2007) Rented and owner occupied housing: A descriptive study for two countries-Turkey and the Netherlands, Paper presented at ENHR 2007 International Conference 'Sustainable Urban Areas', Rotterdam. (http:/ / www.enhr2007rotterdam.nl/pages/ papersdownload.htm)

SARIOĞLU, G. P. (2008) Entry to Home ownership profiles in Turkey and the Netherlands, paper presented at ENHR Working Group Comparative Housing Policy Seminar, 23-24 October 2008, İstanbul.

SARIOĞLU, G. P. (2009) Entry to home ownership: A comparison between Turkey and the Netherlands, unpublished Ph.D. Thesis, METU Department of City and Regional Planning, Ankara.

TAYLAN, A. (2003) Hanehalklarının Konuta Erişebilirliği, Konut Kurultayı, Şehir Plancıları Odası, Mayıs 2002, İstanbul; 448-60.

TURKSTAT (2003) 2000 Census of Population: Social and Economic Characteristics of Population, Pub. No: 2759, Ankara.

TURKSTAT (1993) 1990 General Population Census (GPC), Socio-economic characteristics of population; 186.

VROM (1997) Housing in the Netherlands, Vrom, The Haag.

WBO (2002) Housing Demand Survey raw data, Vrom. 
Alind1: 28.07.2010

Anahtar Sözcükler: ev sahipliği; konut sistemi;,Türkiye; Hollanda.

\section{EV SAHİPLIĞİNE GEÇIŞS PROFILLERİNINN KARŞILAŞTIRILMASI: TÜRKIIYE VE HOLLANDA}

Merkezi konut politikalarının hemen hiç olmadığı bir ortamda yaşanan hızlı kentleşme, Türkiye'ye özgü bir mülkiyet deseninin oluşmasına neden olmuştur: Ev sahipliği \% 64.16 oran ile en yaygın mülkiyet türü iken, tamamı özel olan kiralık kesim, stoğun \% 28.01'ini kapsamaktadır. Konut finansman sisteminin 2007'ye kadar var olmayışı ve uygulanan yetersiz konut politikaları sonucunda serbest piyasa mekanizması konut stoğunun üretiminde önemli yer tutmuştur.

Hollanda' da ise, ev sahipliği ve kiracılık birbirini daha iyi tamamlayan iki mülkiyet biçimi olarak konut sisteminde yer almaktadır. Ülke, kentleşme sürecini Türkiye kadar kısa sürede yaşamamış ve gecekondu gibi kaçak yapılaşma biçimlerine pek rastlanmamıştır. Bu nedenle, konut politikalarının başarıyla uygulanması da lanaklı olabilmiştir. Görece daha iyi olan makro ekonomik koşullar ve düşük enflasyon oranları, Türkiye' de olduğu gibi yüksek ev sahipliği tutkusuna yol açmamıştır. Konut sistemi ,düşük gelir grupları için kamu kiralık kısım (\% 35-37), düzensiz ancak orta gelire sahip hanehalkları için özel kiralık kısım (\% 10), ve sabit ve yüksek gelir gruplarının kendi konutlarında oturmasına (\% 56) olanak veren konut sunumları geliştirmiştir.

Konut sistemleri değişik dönem ve mekanlarda farklı mülkiyet biçimlerini özendirebilir. Ülkenin sosyo-ekonomik koşulları ve politikalar, farklı ev sahipliğine erişim modlarını ortaya çıkarır. "Ev sahipliğine geçiş profilleri (ESGP)" olarak gruplanabilecek bu temel profiller, bu makalede, hanehalklarının ev sahibi olmak için izlediği ana erişim yolları olarak tanımlanmıştır. ESGP'lerin tespiti için konut sistemleri açısından birbirinden oldukça farklı iki ülke; Türkiye ve Hollanda arasında bir karşılaştırma yapılmaktadır. Bu amaçla, Türkiye İstatistik Kurumu'nun hazırladığ “ "Hanehalkı Bütçe Anketi" ve Hollanda Konut, Mekansal Planlama ve Çevre Bakanlığı'nın "Konut Talebi Anketi" hamverileri kullanılmakdatır.

Araştırma sonuçlarına göre, ulusal sosyo-ekonomik koşullar ve konut politikaları hanehalklarının mülkiyet tercihlerinde etkili olmaktadır. Saptanan profilLer, her iki ülkede ev sahipliğine geçiş süreci dinamiklerini ortaya çıkarmaktadır. Daha verimli konut politikaların geliştirilmesi ve uygulanması için konut piyasasındaki dinamiklerin ve süreci etkileyen etmenlerin incelenmesi gerekmektedir. Saptanan ESGP'ler Türkiye için görece etkisiz konut politikalarını yansıtmıştır: Bu ESGP'ler genellikle serbest piyasada gelişen bireysel çabalar şeklindedir. Hollanda için bulunan ESGP'ler ise konut sisteminde merkezi role sahip güçlü devlet müdahalelerinin etkisini açıkça ortaya koymuştur.

G. PELİN SARIOĞLU ERDOĞDU; B. CP., M.CP., Ph.D.

Studied City and Regional Planning at METU (B. CP., 2000; M.CP., 2003) and University of Groningen, in The Netherlands (Ph.D. 2010). Participated in several Scientific Research Projects of 'Residential Mobility' and 'Computational Recoding of Residential Mobility Data' between 2002 and 2010. Currently works in the Department of City and Regional Planning at Mersin University. Areas of interest are housing research, comparative housing studies and basic design. 